\title{
Preparation and in vitro studies of MRI-specific superparamagnetic iron oxide antiGPC3 probe for hepatocellular carcinoma
}

This article was published in the following Dove Press journal:

International Journal of Nanomedicine

24 August 2012

Number of times this article has been viewed

Youwei Li ${ }^{1,2}$

Zhengguang Chen ${ }^{3}$

Fei Li'

Jichen Wang ${ }^{4}$

Zongming Zhang ${ }^{1,5}$

'School of Medicine, Tsinghua University, ${ }^{2}$ Department of Radiology, Beijing Chuiyangliu Hospital, ${ }^{3}$ Department of Radiology, Dongzhimen Hospital Affiliated to Beijing University of Chinese Medicine, Beijing; ${ }^{4}$ Department of Radiology, Nanjing BenQ Hospital, Nanjing, ${ }^{5}$ Department of Hepatobiliary Surgery, Futian Hospital, Guangdong Medical College, Shenzhen, People's Republic of China

Correspondence: Zongming Zhang School of Medicine, Tsinghua University, Beijing 100084. Department of Hepatobiliary Surgery, Futian Hospital, Guangdong Medical College, Shenzhen 518033. People's Republic of China Tel +861062796852

Fax +861062796852

Email zhangzongming@mail.tsinghua. edu.cn
Background: The aim of this study was to develop an antiGPC3-ultrasuperparamagnetic iron oxide (USPIO) probe for early detection of hepatocellular carcinoma.

Methods: GPC3 and AFP receptors were selected as biomarkers and conjugated with USPIO nanoparticles coated by dextran with carboxylate groups to synthesize antiGPC3-USPIO and antiAFP-USPIO probes. HepG2 cells (a human hepatocellular carcinoma cell model with high expression of GPC3) were used along with SMMC-7721 cells (a hepatocellular carcinoma cell model with no expression of GPC3), HeLa cells (a cervical cancer model), and HL-7702 (normal hepatocytes) which were used as controls. After incubation with the probes, the iron content in the cells was calculated, USPIO nanoparticles in cells were observed using transmission electron microscopy, and $\mathrm{T} 1$ and $\mathrm{T} 2$ relaxation times were measured with a $1.5 \mathrm{~T}$ magnetic resonance scanner.

Results: AntiGPC3-USPIO probes with a mean hydrodynamic diameter of $47 \mathrm{~nm}$ showed good biological compatibility. Transmission electron microscopic images indicated that the amount of USPIO nanoparticles taken up was significantly higher in HepG2 cells incubated with antiGPC3-USPIO than that in HepG2 cells incubated with antiAFP-USPIO or USPIO nanoparticles and that in the SMMC-7721 or HeLa cells incubated with antiGPC3-USPIO probes, antiAFP-USPIO probes, or USPIO nanoparticles. The higher the concentration and the longer the incubation time, the greater the number of USPIO nanoparticles found in the cells. No USPIO nanoparticles were found in the HL-7702 cells. All of the HepG2, SMMC-7721, and HeLa cells incubated with antiGPC3-USPIO, antiAFP-USPIO, or USPIO nanoparticles were able to shorten the T1 and T2 values in agar solution, especially the T2 images of HepG2 cells incubated with antiGPC3-USPIO probes

Conclusion: AntiGPC3-USPIO probes can be utilized as a specific magnetic resonance targeting contrast agent for early detection of hepatocellular carcinoma. Using a $1.5 \mathrm{~T}$ magnetic resonance scanner, the optimal time for imaging HepG2 cells was around 2-4 hours after incubation with antiGPC3-USPIO probes.

Keywords: magnetic resonance imaging, hepatocellular carcinoma, HepG2 cells, superparamagnetic iron oxide antiGPC3-USPIO probe

\section{Introduction}

Hepatocellular carcinoma is the fifth most common malignant tumor worldwide, with $50 \%$ of cases occurring in China. Hepatocellular carcinoma usually occurs in patients with chronic parenchymal liver disease, especially chronic infection with hepatitis B or C virus or cirrhosis. ${ }^{1}$ The results of treatment are unsatisfactory because hepatocellular carcinoma cannot be diagnosed in its early stages, and symptoms only appear when the disease is advanced. Therefore, early detection of hepatocellular carcinoma is very important. 
Many molecular magnetic resonance imaging (MRI) methods have been reported to be able to detect and diagnose hepatocellular carcinoma. One involves targeting normal hepatocytes, whereby arabinogalactan can be taken up by normal hepatocytes when combined with sialoglycoprotein receptors on the surface of normal liver cells. When arabinogalactan is coupled with paramagnetic particles to create a molecular magnetic resonance (MR) probe specific for sialoglycoprotein receptors, it can be used to decrease the signal intensity of normal hepatocytes. Hepatocellular carcinoma cells expressing no sialoglycoprotein receptors do not change their signal intensity, and can be identified by MRI because of the increasing contrast between the cancer cells and normal surrounding tissues by magnetization of the probes. This technique is especially useful for improving our ability to diagnose a small hepatocellular carcinoma. ${ }^{2-4}$

Another method involves targeting the stromal components of tumor tissue and exploits the fact that the cell adhesion molecule, integrin $\alpha v \beta 3$, is highly expressed on activated endothelial cells during angiogenesis but is weakly expressed on resting endothelial cells and in most normal organ systems. As a ligand corresponding to integrin $\alpha v \beta 3$, RGD peptide is an oligopeptide containing an arginine-glycine-aspartic acid motif, which can recognize and combine selectively with integrin $\alpha v \beta 3$. In recent years, many investigators have synthesized RGD molecular probes to image tumors and have provided a promising future for early diagnosis of hepatocellular carcinoma. ${ }^{5-7}$

A further method involves targeting tumor cell receptors, whereby ligands or antibodies corresponding to biologic markers expressed by hepatocellular carcinoma cells are coupled with an MR contrast agent to synthesize a molecular MR probe, which can be connected to or incorporated into hepatocellular carcinoma cells using the principle of antigenantibody binding. The tumor cells can then be imaged using this probe and an MR scanner. Corbin et $\mathrm{al}^{8}$ injected LDLgadolinium probes (which couples low-density lipoproteins [LDL] with gadolinium ions) into nude mice implanted with a HepG2 cell line expressing LDL receptors for MR imaging. They found that liver tissue was enhanced initially, and the signal intensity of the tumor then increased gradually. By 24 hours, signal enhancement within the tumor had increased dramatically and the boundary of the tumor was clear. A clear time intensity difference between tumor tissue and normal liver tissue was found, with enhancement of the liver starting to disappear at this time. Therefore, it was concluded that LDL can provide a platform for molecular MR imaging when used to characterize liver tumors. Crich et $\mathrm{al}^{9}$ also reported that LDL can be used as a carrier to transfer a lipophilic gadolinium complex into a tumor cell.

However, these methods have several limitations. First, arabinogalactan-labeled superparamagnetic iron oxide (USPIO) nanoparticles can only identify normal hepatocytes expressing sialoglycoprotein receptors, whereas those lesions that do not express sialoglycoprotein receptors, including hepatocellular carcinoma, metastases, and cysts, show the same intensity on MRI, so this method is not specific for characterizing lesions. Second, the concentration of paramagnetic material required for MRI is $10-100 \mu \mathrm{M}$. However, the concentration of the antigen at the tumor site is only up to $0.1 \mu \mathrm{M}$, so it has been postulated that $100-1000$ gadolinium ions would have to be bound to each antibody molecule to reach a concentration of gadolinium in the tumor which is high enough to influence its MRI signal intensity. ${ }^{10}$ Binding numerous gadolinium ions to an antibody causes a reduction in its immunologic activity. ${ }^{11}$ Ferromagnetic particles show a marked ability to shorten the relaxation rate. Particles with a diameter of $5 \mathrm{~nm}$ can generate a net magnetic moment $10^{3}$ times larger than paramagnetic particles of the same size. ${ }^{12}$ In addition, these nanoparticles have strong magnetic susceptibility.

In order to make a useful MR probe, it is important to select a specific marker on the tumor cell. This biomarker must have high specificity, high affinity, and high capability of differentiating hepatocellular carcinoma from regenerating nodules, regardless of the etiology or stage of hepatic pathology. Moreover, the marker should be able to be detected in the early stages of the disease with high sensitivity. In addition, the detection process should have good repeatability and be nontraumatic. ${ }^{13}$ Alfa fetoprotein (AFP) is the most utilized surveillance biomarker for hepatocellular carcinoma. Its specificity and sensitivity for the disease is in the range of $76 \%-96 \%$ and $40 \%-65 \%$, respectively. ${ }^{14,15}$ However, as a marker, AFP has several limitations in diagnosing hepatocellular carcinoma. Firstly, AFP levels in some patients with chronic hepatic pathology, such as viral hepatitis, cirrhosis, or other tumors (mainly of the digestive tract, including pancreatic, gastric, colorectal, and gallbladder carcinomas) may be increased even without detectable hepatocellular carcinoma. The false-positive and false-negative rates with AFP in the diagnosis of hepatocellular carcinoma are up to $40 \%$. The positive predictive value of AFP is significantly lower in patients with viral hepatitis than in those with nonviral hepatitis ( $70 \%$ versus $94 \%$ ). ${ }^{15}$ Secondly, the serum AFP concentration is proportional to the size of the tumor, and the sensitivity of AFP decreases from $52 \%$ to $25 \%$ when the tumor 
diameter decreases from $>3 \mathrm{~cm}$ to $<3 \mathrm{~cm}$. In addition, well differentiated and degenerative hepatocellular carcinomas show only slightly elevated levels of AFP. Further, the detection rate of small hepatocellular carcinomas, ie, those with a diameter $<1 \mathrm{~cm}$, is poor. ${ }^{16}$ Therefore, biomarkers with higher sensitivity and higher specificity are urgently needed to screen for hepatocellular carcinoma. Recent studies have shown that glypican-3 (GPC3) a carcinoembryonic antigen, is a more sensitive and more specific biomarker for hepatocellular carcinoma, and can be used to detect earlystage disease. ${ }^{17-19}$

In this study, we used GPC3 as a specific marker for hepatocellular carcinoma. The GPC3-associated monoclonal antibody was coupled with USPIO nanoparticles to synthesize a molecular MR probe. The aim of this research was to image early-stage hepatocellular carcinoma cells using 1.5 T MRI to enable early diagnosis of the disease. As a control study, we coupled antiAFP antibodies with USPIO nanoparticles to synthesize an antiAFP-USPIO probe for in vitro experimentation because AFP is the most widely utilized surveillance biomarker for hepatocellular carcinoma.

\section{Materials and methods Preparation of antiGPC3-USPIO and antiAFP-USPIO probes}

USPIO nanoparticles coated by dextran with carboxylate groups were kindly provided by Professor Wangleyu, Department of Chemistry, Beijing University of Chemical Technology. The antiGPC3 antibody was purchased from Thermo Company, and the antiAFP antibody was sourced from Baitai Biotechnology Co, Ltd (Beijing, China).

A one-pot coupling method was used to prepare the antiGPC3-USPIO and antiAFP-USPIO molecular MR probes. Next, $3 \mathrm{mg}$ of 1-(3-dimethylaminopropyl)-3ethylcarbodiimide hydrochloride (EDC) and $6 \mathrm{mg}$ of sulfoN-hydroxysuccinimide (NHS) were dissolved in $1.5 \mathrm{~mL}$ of phosphate-buffered solution ( $\mathrm{pH} 7.4$ ), and $0.2 \mathrm{~N} \mathrm{HCl}$ was then titrated into the mixed solution, ending with a $\mathrm{pH}$ of 5.0. Thirty minutes later, $3 \mathrm{~mL}$ of carboxylated dextran-coated USPIO $5 \mathrm{mg} / \mathrm{mL}$ were added. After 2 hours, the antibodies (1.5 mg of antiAFP antibody or $300 \mu \mathrm{g}$ of antiGPC3 antibody) were added, stirred until fully mixed, and allowed to react for 3 hours. Finally, the $\mathrm{pH}$ of the solution was adjusted to 7 by titration with $0.2 \mathrm{~N} \mathrm{NaOH}$. After 30 minutes, the solution was centrifuged and the supernatant was discarded. The USPIO-antibody probes were resuspended in phosphatebuffered solution at $4^{\circ} \mathrm{C}$ before use.
The average core size, morphology, and size distribution of the samples were examined using transmission electron microscopy (TEM, Hitachi 7600, Tokyo, Japan) with a voltage of $100 \mathrm{kV}$ in the magnification range of 40,000-60,000×. Samples prepared for TEM measurement were dropped onto a 200-mesh copper grid, then air-dried at room temperature before being loaded into the microscope. Structural information from assembly of the USPIO nanoparticles was obtained by X-ray diffraction on a Shimadzu XRD-7000 diffractometer (Shimazdu, Tokyo, Japan). To measure the hydrodynamic diameters of the magnetic molecular probes, dynamic light scattering was performed using a Malvern laser granulometer (Zetasizer Nano ZS90, Malvern Instruments, Worcestershire, UK) at $25^{\circ} \mathrm{C}$. Their magnetic properties and magnetic saturation were set using a super conducting quantum interference device.

\section{Cell culture}

HepG2 cells are human hepatocellular carcinoma cells expressing GPC3, confirmed by Western blotting (see Supplementary Figure S1). Normal HL-7702 hepatocytes, SMMC-7721 hepatocellular carcinoma cells, and HeLa (immortalized cervical cancer) cells lacking GPC3 expression or AFP receptors are used as negative controls. These cells were cultivated in Dulbecco's Modified Eagle's Medium supplemented with $10 \%$ fetal bovine serum and $1 \%$ penicillin-streptomycin at $37^{\circ} \mathrm{C}$ in a $5 \% \mathrm{CO}_{2}$ atmosphere.

\section{Experiment I: concentration-dependent uptake by HepG2 cells}

HepG2 cells, normal HL-7702 hepatocytes, SMMC7721 cells, and HeLa cells were seeded into nine-well plates. Each well contained $5 \mathrm{~mL}$ of medium and $1 \times 10^{7}$ cells. The cells were incubated with antiAFP-USPIO, antiGPC3USPIO, or USPIO for 4 hours in a humidified $5 \% \mathrm{CO}_{2}$ atmosphere at $37^{\circ} \mathrm{C}$. The iron concentration in each well was increased from $62.5 \mu \mathrm{g} \mathrm{Fe} / \mathrm{mL}$ to $250 \mu \mathrm{g} \mathrm{Fe} / \mathrm{mL}$ to $750 \mu \mathrm{g} \mathrm{Fe} / \mathrm{mL}$. Afterwards, in order to achieve separation from unbound particles, the adherent cells were washed three times in phosphate-buffered solution $(0.1 \mathrm{~mol} / \mathrm{L}, \mathrm{pH} 7.4)$, trypsinized, and centrifuged for sedimentation (10 minutes, $250 \mathrm{~g}, 20^{\circ} \mathrm{C}$ ). The cells were then resuspended in $1 \mathrm{~mL}$ of phosphate-buffered solution and the cell number was counted using a hematocytometer. The cells were then equally divided into four groups $\left(2.5 \times 10^{6}\right.$ cells per group). The first group was used to observe cell construction by TEM, the second group was used to calculate the iron content of the cells, the third group was used to test cell viability with flow cytometry 
in the second experiment, and the fourth group was used to measure $\mathrm{T} 1$ and $\mathrm{T} 2$ relaxivity.

\section{Experiment 2: time-dependent uptake by HepG 2 cells}

HepG2 cells, normal HL-7702 hepatocytes, SMMC7721 cells, and HeLa cells were cultivated in nine-well plates at an approximate density of $1 \times 10^{7}$ cells/well in $5.0 \mathrm{~mL}$ of medium. The cells were incubated with antiAFP-USPIO, antiGPC3-USPIO, or USPIO at $37^{\circ} \mathrm{C}$ for one, 2 , or 4 hours at a $\mathrm{Fe} / \mathrm{mL}$ concentration of $750 \mu \mathrm{g}$. After incubation, the medium was removed and the cells were washed repeatedly with phosphate-buffered solution to remove unbound iron nanoparticles. Finally, cell numbers were counted using a hematocytometer. The cells were equally divided into four groups $\left(2.5 \times 10^{6}\right.$ cells per group) and uptake was measured using the same method as that used in the first experiment.

\section{Iron content in HepG2 cells}

The flame atom absorbing law was used to measure the iron content in all cell samples. Briefly, $2.5 \times 10^{6}$ cells were lysed using 65\% nitric acid, and deionized water was then added into the mixed solution to a total volume of $200 \mu \mathrm{L}$. Exactly $40 \mu \mathrm{L}$ of the solution was aspirated using a micropipette. After the sample absorbed onto the tip of micropipette was wiped away, the micropipette was dipped to 3-4 $\mathrm{mm}$ below the fluid surface in a centrifuge tube containing $1.2 \mathrm{~mL}$ of diluted solution, and the sample was then discharged slowly, ie, a $40 \mu \mathrm{L}$ sample of the dilute solution had been absorbed and discharged. This process was repeated twice. The sample prepared was investigated using atomic absorption spectroscopy (BHS 100, Bohui Innovation Technology Co, Ltd, Beijing, China).

\section{Cell uptake of USPIO nanoparticles}

The cells, partitioned by the method described above, were fixed for 24 hours with stationary liquid phase for electron microscopy. The samples were cut into $1 \mathrm{~mm}^{3}$ cubes using a sharp double-edged knife. The blocks were prefixed with $2.5 \%$ glutaraldehyde and then placed in a refrigerator at $4^{\circ} \mathrm{C}$. After being washed three times in phosphate-buffered solution ( $\mathrm{pH}$ 6.8), the blocks were postfixed in 1\% osmium tetroxide for 1.5 hours. The samples were again washed three times using phosphate-buffered solution ( $\mathrm{pH} \mathrm{6.8)} \mathrm{before}$ dehydration. The samples were dehydrated through a series of alcohol concentrations $(50 \%, 70 \%, 80 \%, 90 \%$, and $100 \%)$. During the dehydration process, alcohol concentrations of $50 \%, 70 \%, 80 \%$, and $90 \%$ were used in one step, while an alcohol concentration of 100\% needed three steps. Each dehydration step lasted 15 minutes. Following the final dehydration step, replacement with 100\% alcohol and acetone was performed twice, once using both alcohol and acetone at a ratio of $1: 1$ and once with acetone only for 10 minutes. Next, one part each of the samples was immersed in a reagent comprising acetone and epoxy resin 812 embedding medium at a ratio of 1:1.5 for one hour, and the other parts were set in an embedding medium overnight. When permeation had finished, the samples were polymerized under constant incubation at $40^{\circ} \mathrm{C}$ for 17 hours, at $45^{\circ} \mathrm{C}$ for 24 hours, and at $60^{\circ} \mathrm{C}$ for 17 hours. Finally, the samples were cut into slices $70 \mathrm{~nm}$ thick using a microtome (Leica EM UC6). Once stained in uranyl acetate and lead citrate trihydrate, the slices could be observed by TEM at $80 \mathrm{kV}$.

\section{Relaxivity of cells incubated with antiAFP- USPIO, antiGPC3-USPIO, or USPIO}

\section{Preparation of samples for MRI}

First, $3 \mathrm{~mL}$ of $2 \%$ agar $\left(50^{\circ} \mathrm{C}\right)$ mixed with $2.5 \times 10^{6}$ HepG2 cells, HL-7702 hepatocytes, SMMC-7721 cells, or HeLa cells incubated with antiAFP-USPIO, antiGPC3USPIO, or USPIO were poured into $5 \mathrm{~mL}$ tubes, with care taken to exclude air bubbles. We then turned the tubes three times to maintain the homogeneity of the suspensions, and subsequently cooled them down to room temperature for MRI.

\section{MRI scanning}

MRI scanning of the test tubes was performed on a 1.5 T MR scanner (Excite, GE Medical Systems, Milwaukee, WI) with a standard circularly polarized quadrature knee coil. To avoid susceptibility to air interface artifacts in the scans, all the tubes were placed in a water-containing plastic vessel at room temperature $\left(20^{\circ} \mathrm{C}\right)$. Morphologic MRI was done using a T1-weighted spin-echo sequence (repetition time/echo time 500/9 msec, NEX 1), a T2-weighted spin-echo sequence (repetition time/echo time 2500/52 msec, NEX 2), and T2*weighted gradient echo sequence (repetition time/echo time/ flap angle 460/17.0/20 , NEX 3). For measuring T1 relaxation times, axial spin-echo sequences were applied with multiple repetition times of 1200, 900,600, $300 \mathrm{msec}$, and an echo time of 9 msec. Axial T2-weighted spin-echo images were used with a repetition time of $2000 \mathrm{msec}$ and increasing echo times of 13, 26, 39, and $52 \mathrm{msec}$ for T2 measurements. The field of view, matrix size, slice thickness, and NEX for all of the sequences were set at $160 \times 120 \mathrm{~mm}^{2}, 160 \times 192$ pixels, $5 \mathrm{~mm}$, and 1 , respectively. 


\section{Data analysis}

T1-weighted and T2-weighted spin-echo and T2*-weighted images were analyzed qualitatively at $1.5 \mathrm{~T}$. The signal intensities of tubes containing HepG2 cells incubated with antiAFP-USPIO, antiGPC3-USPIO, or USPIO were compared visually, while the signal intensities of tubes containing normal HL-7702 hepatocytes, SMMC-7721 cells, or HeLa cells incubated with antiAFP-USPIO, antiGPC3-USPIO, or USPIO were also compared.

The MR data acquired using the methods described above were imported into the Function tool (Advantage Workstation AW 4.2) on the workstation. T1 and T2 maps were calculated based on the assumption of a monoexponential signal decay. T1 maps were calculated from four spin-echo images with a fixed echo time of $9 \mathrm{msec}$ and various repetition times $(1200,900,600$, and $300 \mathrm{msec}$ ) using a nonlinear function least-square curve fitted on a pixel-by-pixel basis. 2 maps were calculated accordingly from four spin-echo images with a fixed repetition time of $2000 \mathrm{msec}$ and a group of echo times (13, 26, 39, and $52 \mathrm{msec})$. The $\mathrm{T} 1$ and T2 relaxation times of HepG2 cells taking up USPIO nanoparticles and normal HL-7702 hepatocytes, SMMC-7721 cells, or HeLa cells incubated with antiAFP-USPIO, antiGPC3-USPIO, or USPIO were then derived by drawing ROI (regions of interest) on calculated T1 and T2 maps.

\section{Statistical analysis}

The mean value and standard error of the mean for the quantities of iron within the HepG2, SMMC-7721, or HeLa cells after incubation were calculated three times each using atomic absorption spectroscopy. Differences in these quantitative data for HepG2, SMMC-7721, or HeLa cells after incubation with different iron oxide compounds, iron oxide concentrations, and incubation periods were compared using Student's $t$-test. Six ROI were drawn for each sample relaxation measurement. T1 and T2 values were also displayed as the mean and standard deviation. A two-tailed paired $t$-test was run to compare differences in the data. When the data showed a normal distribution with homogenous variance, one-way analysis of variance was used; otherwise, the ranksum test was used. A difference was considered to be statistically significant at $P<0.05$. All statistical computations were run on professional statistical software, ie, SPSS version 11.5 (SPSS Inc, Chicago, IL, sequence license 30001359390).

\section{Results}

\section{Magnetic molecular probe properties}

The average core size, size distribution, and morphology were confirmed using TEM. As shown in Figure 1A, the magnetic molecular probe showed a spherical core-shell structure with a core diameter of 5-8 $\mathrm{nm}$. The nanoparticles were homogeneous in size and had good dispersity in solution. The X-ray diffraction pattern of the USPIO nanoparticles (Figure 1B) demonstrated that the position and relative intensity of the diffraction peaks matched well with the standard $\mathrm{Fe}_{3} \mathrm{O}_{4}$ powder diffraction data. The average particle diameter estimated from Scherrer's formula was consistent with that determined by statistical analysis of the TEM images. Dynamic light scattering revealed a slightly broader distribution size, and the mean hydrodynamic diameter of the magnetic molecular probes was $47 \mathrm{~nm}$ (Figure 1C).

The superparamagnetic behavior of the nanoparticles was checked by measurement of magnetization using a super conducting quantum interference device. The hysteresis curve (Figure 1D) shows the superparamagnetic characteristics at room temperature, indicating that thermal energy can overcome the anisotropy energy barrier of a single particle, and in the absence of an external field, the net magnetization of the particle assembly is zero. The nanoparticle magnetic saturation was $35.5 \mathrm{emu} / \mathrm{g}$ at $0.6 \mathrm{~T}$, with a coercivity of zero.

Iron content measured by the flame atom absorbing law was $3.60 \mathrm{mg}$ in the antibody-USPIO. Free antibody content in the supernatant fluid $(5.1 \mathrm{~mL})$ was determined using an ultraviolet-visible spectrophotometer. The results showed that the concentration of antiGPC 3 was $12.0 \mu \mathrm{g} / \mathrm{mL}$ and that of antiAFP was $33.0 \mu \mathrm{g} / \mathrm{mL}$. Therefore, the contents of bound antiGPC3 and bound antiAFP were $238.8 \mu \mathrm{g} / 15 \mathrm{mg}$ and $1331.7 \mu \mathrm{g} / 15 \mathrm{mg}$, while the coupling efficiencies are $15.9 \%$ and $88.8 \%$, respectively. Each USPIO nanoparticle could bind three GPC3 antibodies or 12 AFP antibodies.

\section{Amount of probe and USPIO nanoparticle uptake by cells}

The amount and distribution of USPIO nanoparticles in HepG2, SMMC-7721, and HeLa cells incubated with antiGPC3-USPIO, antiAFP-USPIO, or USPIO nanoparticles were observed using TEM. The results demonstrate that the amount of USPIO nanoparticles in HepG2 cells incubated separately with antiGPC3-USPIO, antiAFP-USPIO, or USPIO nanoparticles varied considerably, the largest quantity being in HepG2 cells incubated with antiGPC3-USPIO, the second largest quantity being in $\mathrm{HepG} 2$ cells incubated with antiAFP-USPIO, and the smallest quantity being in HepG2 cells incubated with USPIO nanoparticles. However, the amount of USPIO nanoparticles in SMMC-7721 cells or HeLa cells incubated with antiGPC3-USPIO, antiAFPUSPIO, or USPIO nanoparticles was significantly less 
A

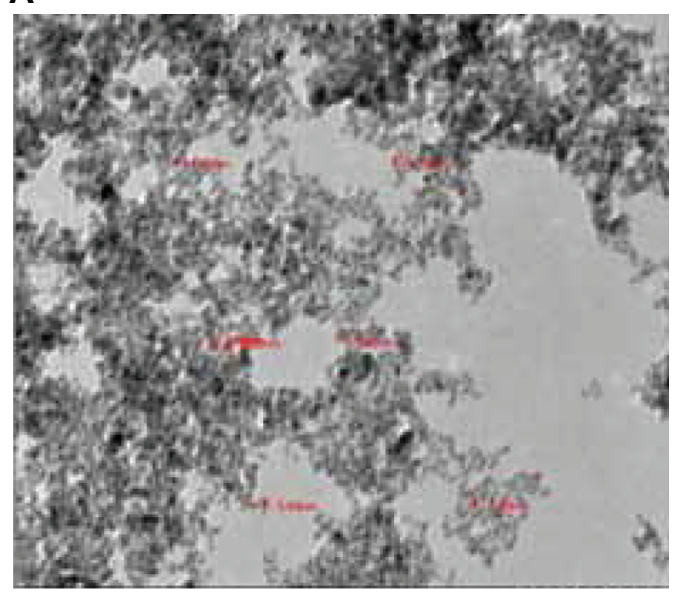

C

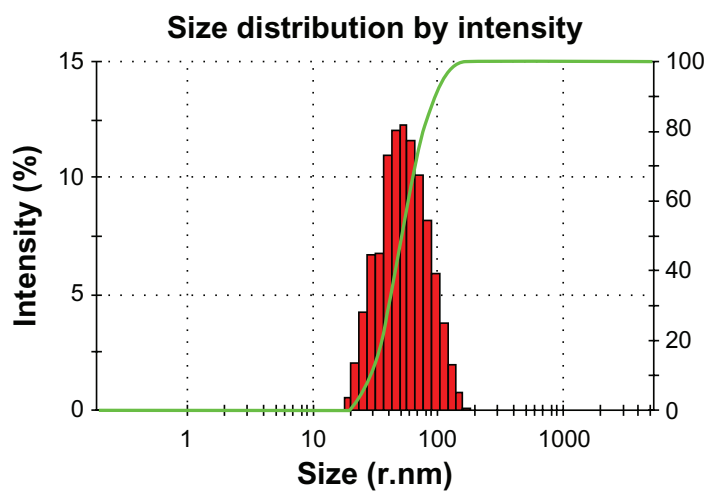

B

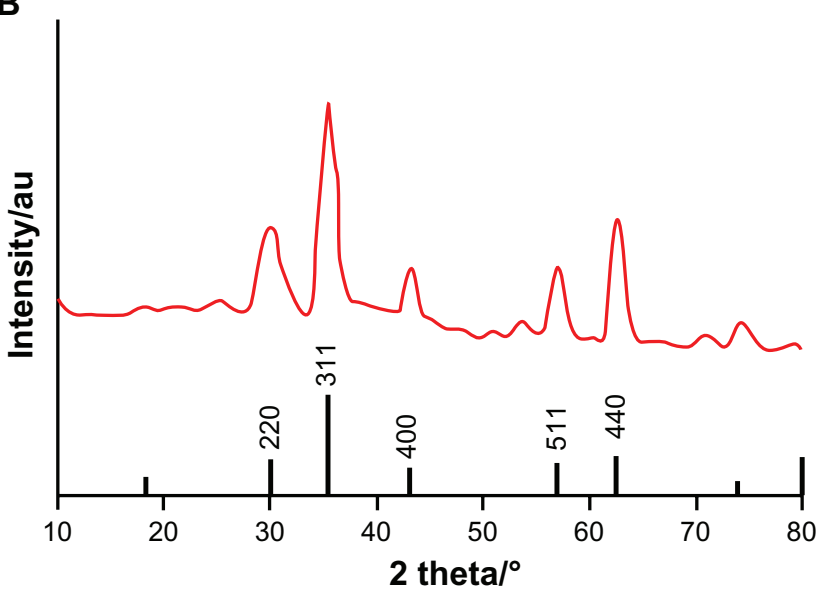

D

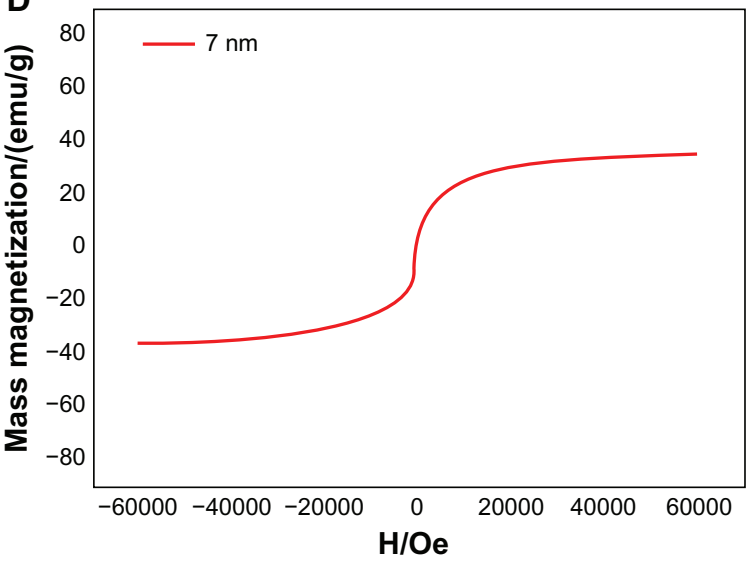

Figure I Characteristics of the antiGPC3 USPIO probes and the USPIO crystals. (A) Hitach 7600 TEM demonstrates the size and morphology of the magnetic molecular probes with a magnification of 40,000. (B) X-ray diffraction pattern of the USPIO nanoparticle assembly. The samples were deposited on glass substrates. Diffraction pattern was collected on a Shimadzu XRD-7000 diffractometer with $\lambda=0.15406 \mathrm{~nm}$. (C) Malvern Zetasizer Nano ZS90 laser granulometer showed the mean hydrodynamic diameter of the magnetic molecular probes and their distribution. (D) Hysteresis loops of the $7 \mathrm{~nm}$ (red line) magnetic probes at $0.6 \mathrm{~T}$.

Abbreviations: USPIO, ultrasuperparamagnetic iron oxide nanoparticle; antiGPC3 USPIO: the probe was formed using antiglypican-3 monoclonal antibodies coupled with USPIO nanoparticles.

than that in HepG2 cells incubated with antiGPC3-USPIO and slightly different from those in HepG2 cells incubated with antiAFP-USPIO or USPIO nanoparticles. From the first experiment, we can see that the USPIO content within HepG2, SMMC-7721, and HeLa cells increased gradually after 4 hours of incubation as the iron content of the antiGPC3-USPIO, antiAFP-USPIO, and USPIO nanoparticles increased from $62.5 \mu \mathrm{g} / \mathrm{mL}$ to $750 \mu \mathrm{g} / \mathrm{mL}$ (see Figure 2, Figure S2 and Figure S4). Analysis of the TEM images reveals that most particles were in the cytoplasm, especially in the lysosomes. In addition, many vacuoles of different sizes were seen in the cytoplasm, and some contained black particles. Some densely packed cilia appeared near the cell nucleus. Experiment 2 shows that the USPIO nanoparticles were scattered around the cell membrane and cytoplasm after the HepG2, SMMC-7721, and HeLa cells were incubated with $750 \mu \mathrm{g} / \mathrm{mL}$ of iron content in antiGPC3-USPIO, antiAFP-
USPIO, or USPIO nanoparticles for one hour. Two hours later, the amount of USPIO nanoparticles incorporated into the intracellular space increased and fused gradually, while the quantity became very large after 4 hours (Figure 3, Figure S3 and Figure S5). Some cell nuclei contained packed blocks.

However, when the iron concentration increased (from $62.5 \mu \mathrm{g} / \mathrm{mL}$ to $750 \mu \mathrm{g} / \mathrm{mL}$ ) and incubation time increased (from one hour to 4 hours), no USPIO nanoparticles were seen in normal HL-7702 hepatocytes incubated with antiGPC3USPIO, antiAFP-USPIO, or USPIO nanoparticles.

\section{Iron content in HepG2 cells after incubation}

The iron content in the HepG2, SMMC-7721, and HeLa cells in all samples was measured using the flame atom absorbing law. The results demonstrate that the three USPIO preparations were incorporated by the HepG2, 


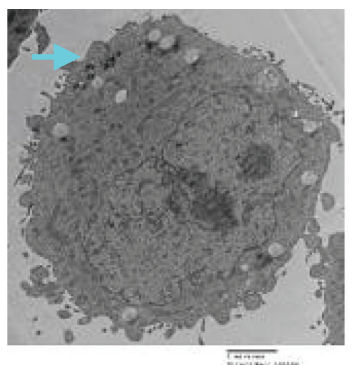

$62.5 \mu \mathrm{g} / \mathrm{mL}$ antiGPC3-USPIO

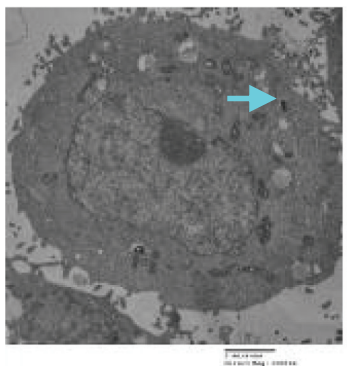

$62.5 \mu \mathrm{g} / \mathrm{mL}$ antiAFP-USPIO

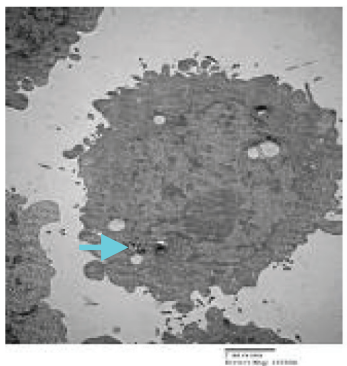

$62.5 \mu \mathrm{g} / \mathrm{mL}$ USPIO

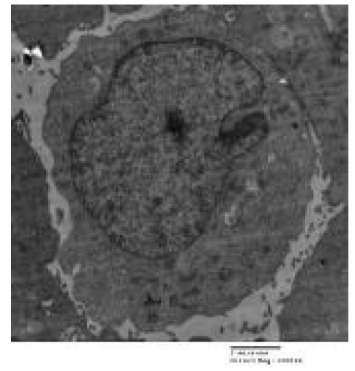

HL-7702 cell

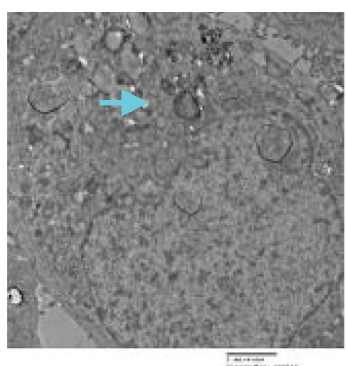

$250 \mu \mathrm{g} / \mathrm{mL}$ antiGPC3-USPIO

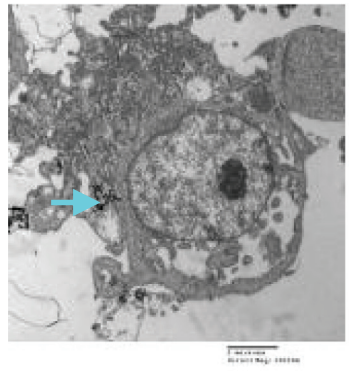

$250 \mu \mathrm{g} / \mathrm{mL}$ antiAFP-USPIO

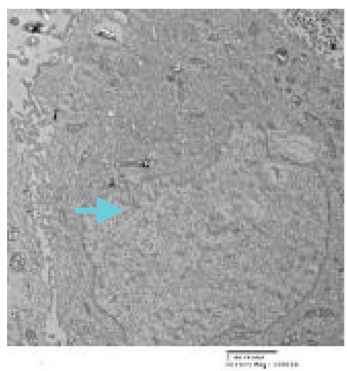

$250 \mu \mathrm{g} / \mathrm{mL}$ USPIO

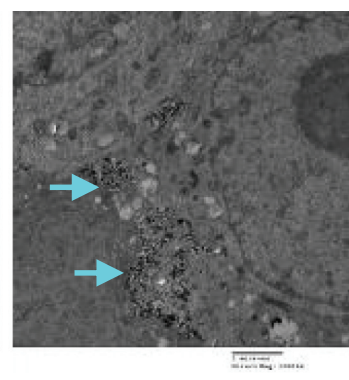

$750 \mu \mathrm{g} / \mathrm{mL}$ antiGPC3-USPIO

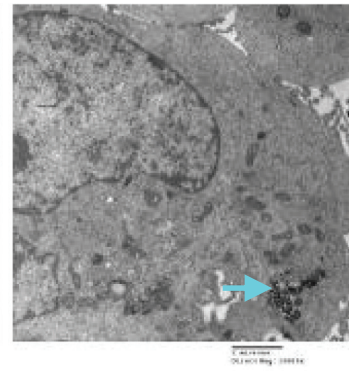

$750 \mu \mathrm{g} / \mathrm{mL}$ antiAFP-USPIO

II

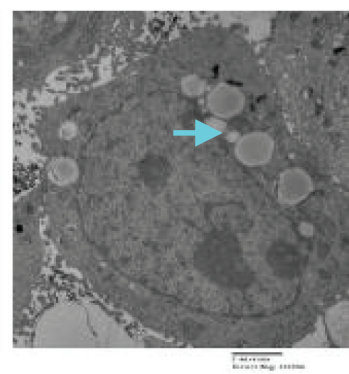

$750 \mu \mathrm{g} / \mathrm{mL}$ USPIO

Figure 2 Hitach 7600 TEM demonstrates construction of the HPG2 cells (I-III), incubated with $750 \mu \mathrm{g} / \mathrm{mL}, 250 \mu \mathrm{g} / \mathrm{mL}$, and $62.5 \mu \mathrm{g} / \mathrm{mL}$ iron content of antiGPC3-USPIO, antiAFP-USPIO and USPIO nanoparticles for $4 \mathrm{~h}$ at $37^{\circ} \mathrm{C}$ in $5 \% \mathrm{CO}_{2}$, with a magnification of 10,000 . As control, the $\mathrm{HL}-7702$ hepatocytes incubated with iron content of $750 \mu \mathrm{g} / \mathrm{mL}$ iron content of antiGPC3-USPIO for $4 \mathrm{~h}$ at the same conditions were also demonstrated by TEM. The HPG2 cells took iron oxides in a concentration-dependent manner. However, the HL-7702 (IV) hepatocytes did not ingest the USPIO nanoparticles.

Note: The arrow indicates the USPIO nanoparticles.

Abbreviations: USPIO ultrasuperparamagnetic iron oxide nanoparticle; antiGPC3 USPIO: the probe was formed using antiglypican-3 monoclonal antibodies coupled with USPIO nanoparticles; antiAFP-USPIO: the probe was formed using antiAFP antibodies coupled with USPIO nanoparticles.

SMMC-7721 and HeLa cells in a concentration-dependent manner. The intracellular iron content was increased when the iron concentration of the nanoparticle preparation was $250 \mu \mathrm{g} \mathrm{Fe} / \mathrm{mL}$ and was increased by a further two-fold at a concentration of $750 \mu \mathrm{g} \mathrm{Fe} / \mathrm{mL}$ compared with a concentration of $62.5 \mu \mathrm{g} \mathrm{Fe} / \mathrm{mL}$. At the same incubation concentrations, the amount of iron incorporated in the HepG2 cells also differed significantly between the antiGPC3-USPIO, antiAFP-USPIO, and USPIO nanoparticles. Uptake of antiGPC3-USPIO was significantly higher and more than twice the uptake of antiAFP-USPIO and USPIO nanoparticles at all concentrations $(P<0.05$, Figure 4A). 


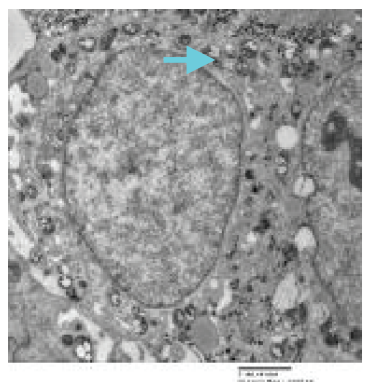

antiGPC3-USPIO $1 \mathrm{~h}$

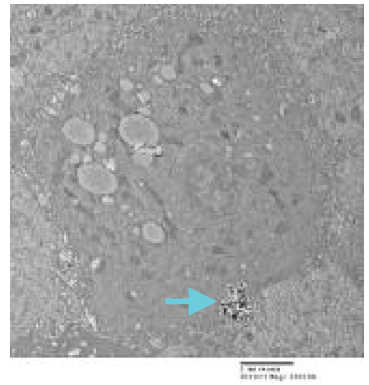

antiAFP-USPIO $1 \mathrm{~h}$

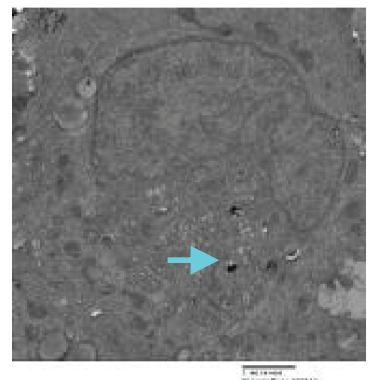

USPIO $1 \mathrm{~h}$

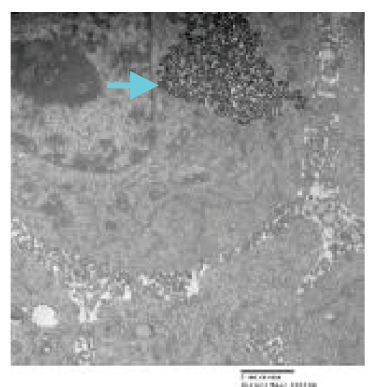

antiGPC3-USPIO $2 \mathrm{~h}$

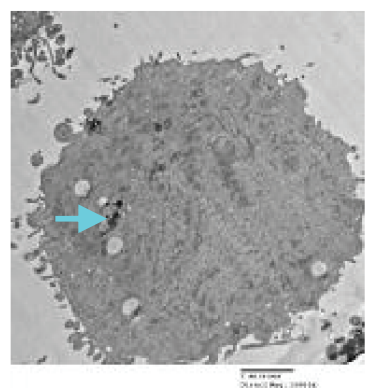

antiAFP-USPIO $2 \mathrm{~h}$

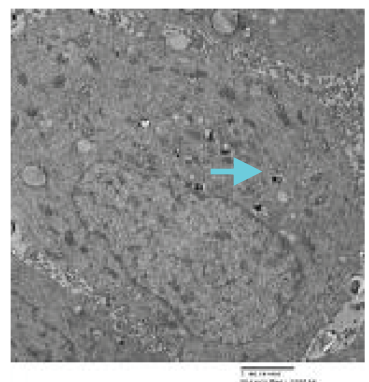

USPIO $2 \mathrm{~h}$

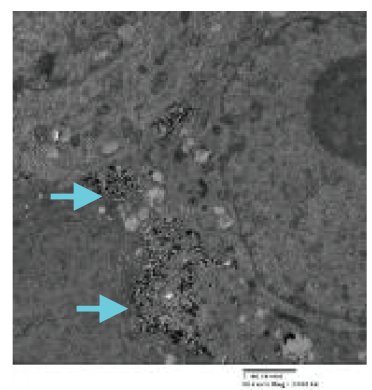

antiGPC3-USPIO $4 \mathrm{~h}$

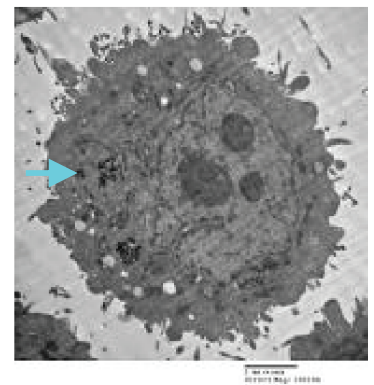

antiAFP-USPIO $4 \mathrm{~h}$

II

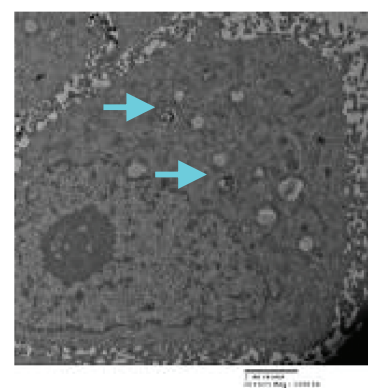

USPIO $4 \mathrm{~h}$

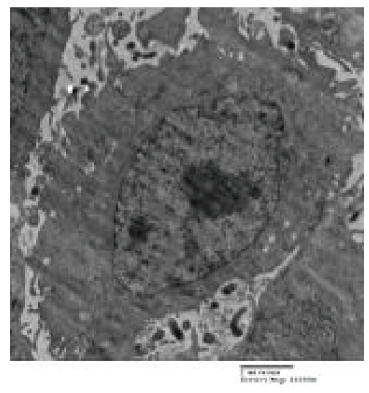

HL-7702 cell

Figure 3 Hitach 7600 TEM demonstrates iron oxide incorporation by HPG2 cells (I-III) and HL-7702 hepatocytes for antiGPC3-USPIO, antiAFP-USPIO or USPIO nanoparticles in a time-dependent manner with a magnification of 10,000. The USPIO nanoparticles scattered around the cell membrane and cytoplasma after the HPG2 cells incubated with iron content of $750 \mu \mathrm{g} / \mathrm{mL}$ for I h. For $2 \mathrm{~h}$ and $4 \mathrm{~h}$ the amount of USPIO nanoparticles incorporated into intracellular increased and fused gradually, and became masses. No USPIO nanoparticle was seen in the HL-7702 hepatocytes during incubation of I h, $2 \mathrm{~h}$ and $4 \mathrm{~h}$ (IV).

Note: The arrow indicates the USPIO nanoparticles.

Abbreviations: USPIO, ultrasuperparamagnetic iron oxide nanoparticle; antiGPC3 USPIO: the probe was formed using antiglypican-3 monoclonal antibodies coupled with USPIO nanoparticles; antiAFP-USPIO: the probe was formed using antiAFP antibodies coupled with USPIO nanoparticles.

The iron content in the SMMC-7721 cells and HeLa cells incubated with antiGPC3-USPIO, antiAFP-USPIO, and USPIO nanoparticles was significantly less than that in HepG2 cells incubated with antiGPC3-USPIO and slightly different from those in HepG2 cells incubated with antiAFPUSPIO and USPIO nanoparticles. A difference in iron content was seen between SMMC-7721 cells and HeLa cells incubated with the probes (antiGPC3-USPIO and antiAFPUSPIO) and the cells incubated with USPIO nanoparticles, the latter being slightly higher (Figure S8A, S8C).

Analysis of the various incubation processes showed that incorporation of iron oxide by HepG2 (Figure 4B), 

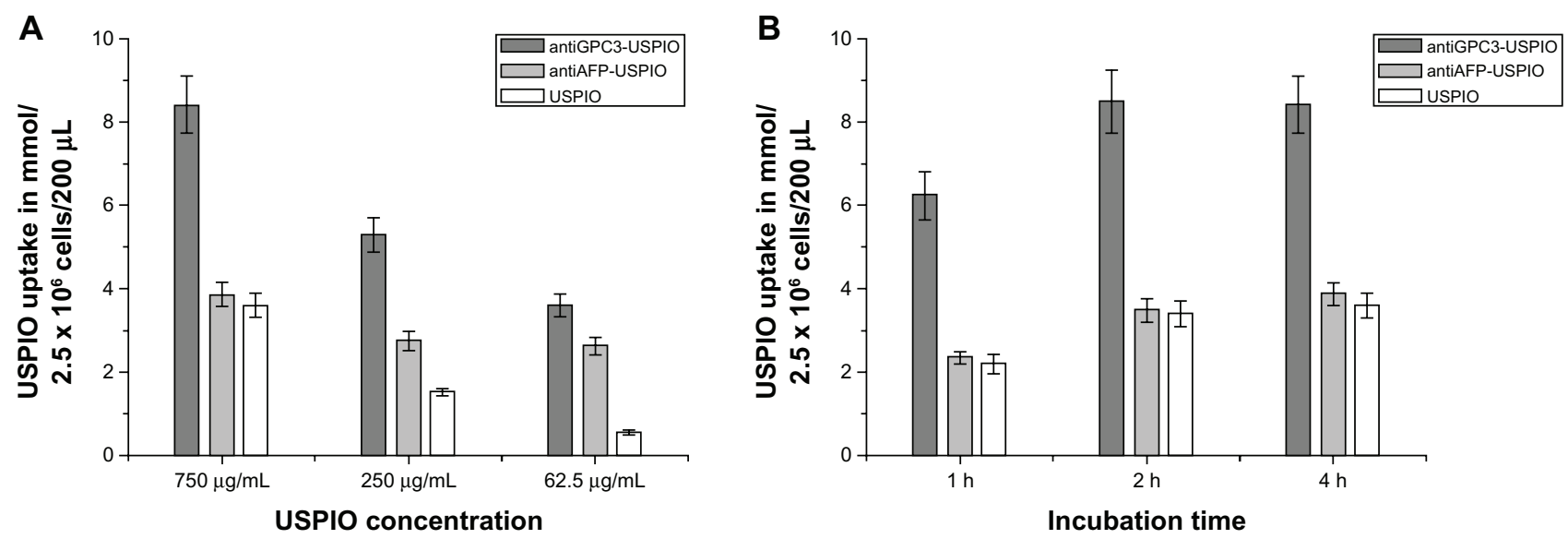

Figure 4 The iron uptakes by HPG2 cells with a concentration-dependent manner (A), by which HPG2 cells were incubated with antiGPC3-USPIO, antiAFP-USPIO and USPIO nanoparticles at iron concentrations of $62.5 \mu \mathrm{g} / \mathrm{mL}, 250 \mu \mathrm{g} / \mathrm{mL}$ and $750 \mu \mathrm{g} / \mathrm{mL}$ for $4 \mathrm{~h}$ under equivalent incubation conditions, or in a time-dependent manner (B), by which HPG2 cells were incubated with $750 \mu \mathrm{g} / \mathrm{mL}$ antiGPC3-USPIO, antiAFP-USPIO and USPIO nanoparticles for I h, $2 \mathrm{~h}$ and $4 \mathrm{~h}$, respectively.

Abbreviations: USPIO, ultrasuperparamagnetic iron oxide nanoparticle; antiGPC3 USPIO: the probe was formed using antiglypican-3 monoclonal antibodies coupled with USPIO nanoparticles; antiAFP-USPIO: the probe was formed using antiAFP antibodies coupled with USPIO nanoparticles.

SMMC-7721 (Figure S8B) and HeLa cells (Figure S8D) was time-dependent for the three agents investigated. The iron content within the HepG2, SMMC-7721, and HeLa cells increased as the incubation time varied from one hour to 4 hours when the concentration of iron was kept constant at $750 \mu \mathrm{g} / \mathrm{mL}$, except for the HepG2 cells incubated with the antiGPC3-USPIO for 2 hours and for 4 hours, in which case no difference was seen. With an equal incubation time, the amount of iron incorporation into HepG2 cells incubated with antiGPC3-USPIO was higher than that in HepG2 cells incubated with antiAFP-USPIO and USPIO nanoparticles and also that in SMMC-7721 and HeLa cells incubated with antiGPC3-USPIO, antiAFP-USPIO, or USPIO nanoparticles. The mean iron content was maximized, and up to $38.1 \mathrm{pg}$ per HepG2 cell incubated with $750 \mu \mathrm{g} / \mathrm{mL}$ antiGPC3-USPIO probes. These results indicate that, using the MRI scanner, it was optimal to image $\mathrm{HepG} 2$ cells with probes having an iron content of $750 \mu \mathrm{g} / \mathrm{mL}$ after 2 hours of incubation. The iron content within HL-7702 hepatocytes incubated with
antiGPC3-USPIO, antiAFP-USPIO, or USPIO nanoparticles was not measured because no USPIO nanoparticles were found in them on TEM.

\section{Relaxivity of HepG2 cells incubated with antiAFP-USPIO, antiGPC3-USPIO, or USPIO}

HepG2, SMMC-7721, and HeLa cells incubated with antiGPC3-USPIO, antiAFP-USPIO, or USPIO nanoparticles could all shorten the T1 and T2 value in agar solution (Table 1). In particular, when compared with HepG2 cells incubated with antiAFP-USPIO or USPIO nanoparticles and SMMC-7721 cells or HeLa cells incubated with antiGPC3-USPIO, antiAFP-USPIO, or USPIO nanoparticles, HepG2 cells incubated with antiGPC3-USPIO showed a statistically significant difference in $\mathrm{T} 2$ values. The higher the concentration, the smaller the values were.

When the concentration of iron was kept constant at $750 \mu \mathrm{g} / \mathrm{mL}$, statistical analysis showed significant $(P<0.05)$

Table I The results of TI and T2 values of HepG2 cells incubated with antiGPC3-USPIO, antiAFP-USPIO, and USPIO

\begin{tabular}{|c|c|c|c|c|c|c|}
\hline & \multicolumn{3}{|l|}{ TI values } & \multicolumn{3}{|l|}{ T2 values } \\
\hline & antiGPC3-USPIO & antiAFP-USPIO & USPIO & antiGPC3-USPIO & antiAFP-USPIO & USPIO \\
\hline $750 \mu \mathrm{g} / \mathrm{mL}$ (I h) & $1713.70 \pm 54.93$ & $3067.10 \pm|7| .2 \mid$ & $3197.68 \pm 237.57$ & $29.781 \pm 0.3424$ & $66.363 \pm 3.0342$ & $70.228 \pm 2.1347$ \\
\hline $750 \mu \mathrm{g} / \mathrm{mL}(2 \mathrm{~h})$ & $794.08 \pm 30.01$ & $2708.75 \pm 98.42$ & $2951.96 \pm 128.81$ & $12.498 \pm 0.6252$ & $56.310 \pm 0.9306$ & $62.121 \pm 1.3715$ \\
\hline $750 \mu \mathrm{g} / \mathrm{mL}(4 \mathrm{~h})$ & $990.36 \pm 5.73$ & $2902.65 \pm 96.95$ & $3050.30 \pm 121.49$ & $14.750 \pm 0.6957$ & $54.270 \pm 0.6315$ & $55.893 \pm 0.9107$ \\
\hline $250 \mu \mathrm{g} / \mathrm{mL}(4 \mathrm{~h})$ & $|957.73 \pm 4| 3.40$ & $2416.15 \pm 97.40$ & $278|.15 \pm 449.7|$ & $39.665 \pm 0.3302$ & $79.015 \pm 1.1951$ & $87.933 \pm 0.6988$ \\
\hline $62.5 \mu \mathrm{g} / \mathrm{mL}(4 \mathrm{~h})$ & $2389.60 \pm 767.14$ & $2791.25 \pm 287.57$ & $3179.61 \pm 88.63$ & $65.398 \pm 0.5238$ & $96.205 \pm 1.8382$ & $102.868 \pm 1.7073$ \\
\hline Control (2\% agar) & 3216.4 & 3345.2 & 3317.1 & 110.9 & 109.8 & II 2.3 \\
\hline
\end{tabular}

Abbreviations: USPIO, ultrasuperparamagnetic iron oxide nanoparticle; antiGPC3 USPIO: the probe was formed using antiglypican-3 monoclonal antibodies coupled with USPIO nanoparticles; antiAFP-USPIO: the probe was formed using antiAFP antibodies coupled with USPIO nanoparticles; h, hours (of incubation time). 
shortening of the T1 and T2 values of HepG2 cells incubated with antiAFP-USPIO and HepG2 cells incubated with USPIO nanoparticles, and the T1 and T2 values decreased gradually as the incubation time increased from 2 hours to 4 hours. The same results were found for SMMC-7721 cells and HeLa cells incubated with antiGPC3-USPIO and antiAFP-USPIO and for SMMC-7721 cells and HeLa cells incubated with USPIO nanoparticles. Differences in shortening of the T1 and T2 values were also seen in HepG2, SMMC-7721, and HeLa cells. However, no statistically significant $(P=0.078)$ difference was seen in shortening of the T1 and T2 values between HepG2 cells incubated with antiGPC3-USPIO for 2 hours and 4 hours. These were directly demonstrated in Figure 5, Figure S6 and Figure S7, in which the signal intensity on T2-weighted images of HepG2 cells incubated with antiGPC3-USPIO $750 \mu \mathrm{g} / \mathrm{mL}$ for 2 hours or 4 hours decreased dramatically, whereas no difference in signal intensity were seen between the other samples (Figure 5A). When the content of antiGPC3USPIO increased from $62.5 \mu \mathrm{g} / \mathrm{mL}$ to $750 \mu \mathrm{g} / \mathrm{mL}$, the signal intensities of the incubated HepG2 cells (Figure 5B), SMMC7721 cells, and HeLa cells decreased gradually, becoming darker on T2-weighted images.

In Table 2, no difference in shortening of T1 and T2 values existed between normal HL-7702 hepatocytes incubated with
antiGPC3-USPIO, antiAFP-USPIO, or USPIO nanoparticles according to the statistical analysis $(P>0.05)$. However, the T1 and T2 values changed with various iron concentrations in the antiGPC3-USPIO, antiAFP-USPIO, and USPIO nanoparticles. The higher the concentration, the smaller the values were.

\section{Discussion}

As an MRI contrast agent for imaging cells, USPIO nanoparticles should be able to combine with cell membranes and enter into cells. There are two main routes via which USPIO nanoparticles can enter into cells, ie, specific and nonspecific endocytosis. Nonspecific endocytosis is a process by which extracellular materials are transported into cells via membrane deformation, whereas specific endocytosis is a process by which extracellular materials are transported into cells via a combination of ligands or antibodies with specific receptors on the cell membrane which regulate infiltration of USPIO nanoparticles into cells. Specific ligands or monoclonal antibodies associated with receptors which are highly expressed on the surface of cells can be coupled with USPIO nanoparticles to synthesize specific MR probes, which actively recognize and combine with receptors in vitro or in vivo and transport the USPIO nanoparticles into the
A

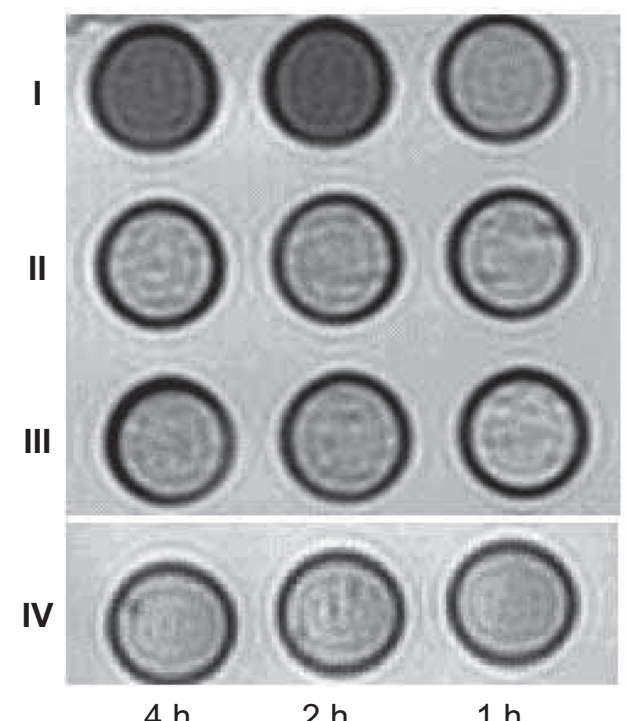

B

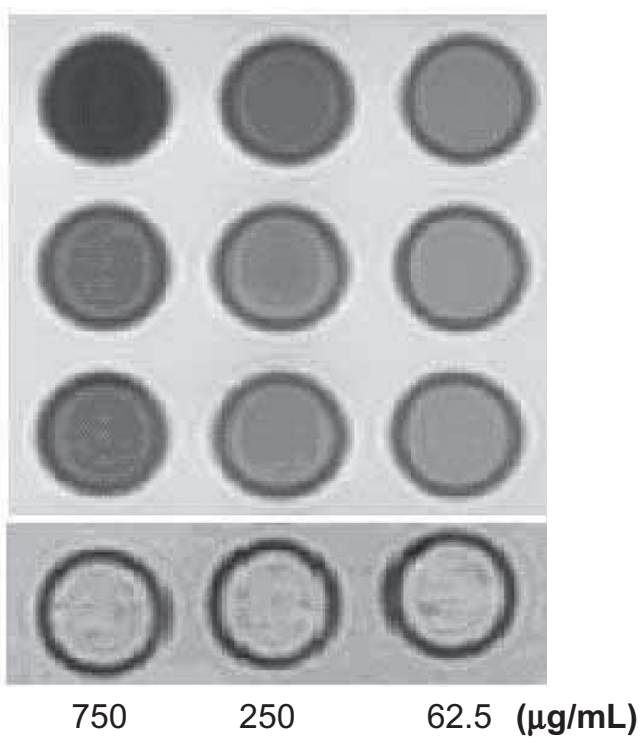

Figure 5 The T2W images (TR/TE $=2500 / 62.5 \mathrm{~ms}$ NEX $2.0 \mathrm{FOV} 192 \times 160$, slice thickness $5 \mathrm{~mm}$ ) of tubes containing $3 \mathrm{~mL}$ solution of $2 \%$ agar mixed with $2.5 \times 10^{6} \mathrm{HepG} 2$ cells incubated with antiGPC3-USPIO, antiAFP-USPIO and USPIO nanoparticles respectively. (A) the HepG2 cells incubated with iron content of $750 \mu \mathrm{gg} / \mathrm{mL}$ in antiGPC3USPIO (I), antiAFP-USPIO (II) and USPIO nanoparticles (III) for I h, $2 \mathrm{~h}$ and $4 \mathrm{~h}$ at $37^{\circ} \mathrm{C}$ in $5 \% \mathrm{CO}_{2}$; the $\mathrm{HL}-7702$ hepatocyte cells incubated with antiGPC3-USPIO in concentration of $750 \mu \mathrm{g} \mathrm{Fe} / \mathrm{mL}$ were displayed as control (IV). (B) the HepG2 cells incubated with varied iron content (left to right: $750 \mu \mathrm{g} / \mathrm{mL}, 250 \mu \mathrm{g} / \mathrm{mL}$, and $62.5 \mu \mathrm{g} / \mathrm{mL}$ ) of antiGPC3-USPIO (I), antiAFP-USPIO (II) and USPIO nanoparticles (III) for $4 \mathrm{~h}$ at $37^{\circ} \mathrm{C}$ in $5 \% \mathrm{CO}_{2}$. As control the $\mathrm{HL}-7702$ hepatocyte cells incubated with antiGPC3-USPIO in corresponding iron content were also revealed (IV).

Abbreviations: USPIO, ultrasuperparamagnetic iron oxide nanoparticle; antiGPC3 USPIO: the probe was formed using antiglypican-3 monoclonal antibodies coupled with USPIO nanoparticles; antiAFP-USPIO: the probe was formed using antiAFP antibodies coupled with USPIO nanoparticles. 
Table 2 The results of TI and T2 values of HL-7702 hepatocyte cells incubated with antiGPC3-USPIO, antiAFP-USPIO, and USPIO

\begin{tabular}{|c|c|c|c|c|c|c|}
\hline & \multicolumn{3}{|l|}{ TI values } & \multicolumn{3}{|l|}{ T2 values } \\
\hline & antiGPC3-USPIO & antiAFP-USPIO & USPIO & antiGPC3-USPIO & antiAFP-USPIO & USPIO \\
\hline $750 \mu \mathrm{g} / \mathrm{mL}(\mathrm{l} \mathrm{h})$ & $2917.38 \pm 270.63$ & $2914.86 \pm 161.34$ & $2860.40 \pm 152.90$ & $62.140 \pm 0.7707$ & $59.728 \pm 0.7223$ & $58.155 \pm 4.0376$ \\
\hline $750 \mu \mathrm{g} / \mathrm{mL}(2 \mathrm{~h})$ & $2911.45 \pm 358.81$ & $3047.93 \pm 158.98$ & $2865.56 \pm 108.20$ & $62.123 \pm 2.5963$ & $60.416 \pm 1.6183$ & $58.735 \pm 2.5504$ \\
\hline $750 \mu \mathrm{g} / \mathrm{mL}(4 \mathrm{~h})$ & $3084.30 \pm 154.22$ & $3082.93 \pm 136.52$ & $3096.65 \pm 218.57$ & $60.791 \pm 0.9578$ & $61.861 \pm 2.1160$ & $59.341 \pm 1.5072$ \\
\hline $250 \mu \mathrm{g} / \mathrm{mL}(4 \mathrm{~h})$ & $3068.18 \pm 195.02$ & $3283.31 \pm 86.69$ & $2970.36 \pm \mid 16.71$ & $85.010 \pm 1.4648$ & $83.568 \pm 1.8863$ & $80.606 \pm 0.6143$ \\
\hline $62.5 \mu \mathrm{g} / \mathrm{mL}(4 \mathrm{~h})$ & $3271.18 \pm 147.61$ & $3220.30 \pm 85.89$ & $3142.83 \pm 141.68$ & $92.326 \pm 2.1640$ & $93.658 \pm 1.8188$ & $93.895 \pm 1.0021$ \\
\hline Control (2\% agar) & 3483.2 & 3395.6 & 3418.7 & 97.3 & 94.2 & 95.1 \\
\hline
\end{tabular}

Abbreviations: USPIO, ultrasuperparamagnetic iron oxide nanoparticle; antiGPC3 USPIO: the probe was formed using antiglypican-3 monoclonal antibodies coupled with USPIO nanoparticles; antiAFP-USPIO: the probe was formed using antiAFP antibodies coupled with USPIO nanoparticles; h, hours (of incubation time).

target cells. The amount of USPIO nanoparticles incorporated into cells through specific endocytosis is several times greater than that via the nonspecific route. ${ }^{20}$ Not only can the probes be used in research and to identify target cells, but a large quantity of USPIO nanoparticles in the cells can also enhance the MR imaging sensitivity. Therefore, specific antibodies attached to a USPIO probe is a problem for MR molecular imaging.

AntiGPC3-USPIO MR probes were synthesized using USPIO nanoparticles coated by dextran with carboxylate groups, on which the hydroxyl groups were partially oxidized by sodium periodate to be able to couple with antiGPC3 antibodies through an aqueous, carbodiimide-mediated process using EDC and sulfo-NHS. A one-pot method was used to synthesize the antiGPC3-USPIO MR probes. The whole process is efficient, simple, and stable. It is well known that there were two traditional methods, ie, singlestep and two-step, which can be used to couple carboxylate particles with amine-containing molecules through an aqueous, carbodiimide-mediated process with EDC and/or sulfo-NHS. ${ }^{21}$ The two-step method has been widely used because of its high quality control, but fussy operation and the strict limitations per step have hindered mass production. We modified the two-step method to synthesize the MR nanoprobe and referred to it as a one-pot method, in which both the activation and coupling processes were completed in entirely aqueous conditions without removing redundant EDC and/or NHS before adding the antibodies. The coupling time was markedly reduced, and our results show that each type of USPIO nanoparticle may bind three GPC3 antibodies or 12 AFP antibodies. This is consistent with findings reported by other laboratories, ${ }^{22}$ when a two-step method has been used to synthesize such probes.

The antiGPC3-USPIO MR probe shows higher specification, which means that it can be used as a targeting marker. We chose GPC3-associated monoclonal antibodies as a targeting marker to couple with USPIO nanoparticles for synthesis of
antiGPC3-USPIO MR probes because the GPC3 expressed strongly on the surface of hepatocellular carcinoma cells is a more sensitive and more specific biomarker for these cells and can be used for early detection and diagnosis of the disease. ${ }^{18,19}$ Our results demonstrate that HepG2 cells with high expression of GPC 3 incubated with antiGPC3-USPIO probes ingested more USPIO nanoparticles, whereas HepG2 cells incubated with antiAFP-USPIO probes or USPIO nanoparticles and SMMC-7721 cells and HeLa cells with no expression of GPC3 incubated with antiGPC3-USPIO probes, antiAFP-USPIO probes, or USPIO nanoparticles absorbed very few USPIO nanoparticles. This indicates that although ligand binding in the GPC3 pathway plays a key role, other routes might also exist. Many studies ${ }^{23-25}$ have demonstrated that USPIO nanoparticles can be taken up by various cells via nonspecific endocytosis, which differ depending on the type of USPIO nanoparticles or cells used. ${ }^{26} \mathrm{Ma}$ and $\mathrm{Gu}^{27}$ explored mechanisms of endocytosis using USPIO nanoparticles coated with aminosilanes and incubated with an SPC-A1 lung cancer cell line. After one hour of incubation, the USPIO nanoparticles coated with aminosilanes were incorporated into the cytoplasm of the lung cancer cells, and the quantity incorporated increased gradually with longer incubation times. These results suggest that lung cancer cells take up USPIO nanoparticles coated with aminosilanes in a dynamic manner.

The USPIO nanoparticle content in HepG2 cells incubated with antiGPC3-USPIO probes for 2 hours showed no difference compared with those incubated for 4 hours, whereas the USPIO nanoparticle content in HepG2 cells incubated with antiAFP-USPIO probes or USPIO nanoparticles and SMMC-7721 cells and HeLa cells incubated with antiGPC3-USPIO probes, antiAFP-USPIO probes, or USPIO nanoparticles increased with the duration of incubation. These findings indicate that USPIO nanoparticles in HepG2 cells incubated with antiGPC3-USPIO probes were phagocytosed via specific endocytosis at a rate which was closely related 
to the number of GPC3 molecules on the cell membrane, and could reach saturation. ${ }^{28}$ However, USPIO nanoparticles in HepG2 cells incubated with antiAFP-USPIO probes or with USPIO nanoparticles and SMMC-7721 cells and HeLa cells incubated with antiGPC3-USPIO probes, antiAFPUSPIO probes, or USPIO nanoparticles were phagocytosed via nonspecific endocytosis, whereby the cells took up the USPIO nanoparticles in a dynamic fashion. ${ }^{27}$ The difference in USPIO nanoparticle content between HepG2 cells incubated with antiAFP-USPIO probes, HepG2 cells incubated with USPIO nanoparticles, and SMMC-7721 and HeLa cells incubated with antiGPC3-USPIO or antiAFP-USPIO probes and with USPIO nanoparticles demonstrated that various tumor cells ingested different quantities of USPIO nanoparticles and the difference existed in the same tumor cells incubated with different USPIO nanoparticles or USPIO nanoparticle preparations.

We need to study whether antiGPC3-USPIO MR probes can combine with target cells in other ways. It is well known that nanoparticles and biological probes can interact with proteins and form a protein corona on their surface when they enter a biological medium. The protein-nanoparticle corona controls the bioactivity of the nanoparticles, ${ }^{29-31}$ rather than the nanoparticle or probe itself. When the nanoparticle-protein corona comes into contact with cells, highly specific proteins, such as antibodies or ligands, become adsorbed onto the nanoparticles, can combine with the cells, activate the endocytosis mechanism, and then enter into the cells via a nonspecific or highly specific route. Therefore, we must consider the effects of specific proteins in the culture medium during such experiments. Some receptors, such as those for transferrin, can be overexpressed on the surface of HepG2 cells ${ }^{32}$ and secrete certain proteins into the culture medium. When these proteins produce a nanoparticle-protein corona, they may become combined with transferrin receptors on the surface of HepG 2 cells, enabling transport of USPIO nanoparticles into the cells. ${ }^{33}$ This hypothesis needs to be studied further.

Our results show that the average content of Fe ions in USPIO nanoparticles in HepG2 cells incubated with $750 \mu \mathrm{g} / \mathrm{mL}$ antiGPC3-USPIO probes was up to $38.1 \mathrm{pg}$ per cell, which is slightly lower than the values reported by other investigators. $^{20,34,35}$ This difference may reflect the nature of the molecular probes used, different kinds of cancer cells used, and the extent of receptor expression on cancer cell membranes. The Fe ion content was sufficient to decrease the signal intensity and shorten the T1 and T2 values of hepatocellular carcinoma cells in $1.5 \mathrm{~T}$ MRI, especially in T2*-weighted images.
After incubation of normal hepatocytes with antiGPC3USPIO, antiAFP-USPIO, or USPIO nanoparticles, the TEM images showed no USPIO nanoparticles in normal hepatocytes. This observation may be related to the short duration of exposure to the nanoparticles. We suggest that the optimal time for imaging HepG2 cells is around 2-4 hours after incubation with antiGPC3-USPIO probes, when HepG2 cells are implanted within normal hepatocytes, and the Fe content of HepG2 cells is maximal. This may be important in future in vivo experiments.

No USPIO nanoparticles were seen in normal hepatocytes, but the T1 and T2 relaxivities of these cells decreased. Exactly why this occurred is not clear. We reviewed our experiment process carefully, and found that identification of hepatocytes with USPIO nanoparticles was incomplete. In our experiment, we found that cell adherence on the walls of the culture medium are associated with the types of cells used, as well as the concentration of USPIO nanoparticles added to the culture medium. The higher the concentration, the poorer the cell adherence on the walls of the culture medium. In addition, cell adherence on the walls of culture medium is related to incubation time, and becomes stronger when the incubation time increases. Cell adherence on the walls of the culture medium is weaker after one hour of incubation, especially when higher concentration of USPIO nanoparticles were added. Once washed thoroughly with phosphate-buffered solution, a large amount of cells was lost. Therefore, the cells were not washed completely in order to ensure a sufficient number of cells for the experiment.

\section{Conclusion}

AntiGPC3-USPIO probes synthesized with GPC3-associated monoclonal antibodies and coupled with USPIO nanoparticles can be taken up in a specific manner by HepG2 cells strongly expressing GPC3 molecules, and can shorten the T1 and T2 values of these cells in a 1.5 $\mathrm{T}$ MR scanner. Therefore, this probe can be used as an MR-specific targeted contrast agent to detect and diagnose early-stage hepatocellular carcinoma. The optimal time for imaging HepG2 cells is 2-4 hours after incubation with antiGPC3-USPIO probes if HepG2 cells are implanted in normal hepatocytes.

\section{Acknowledgments}

This research was financially supported by a grant from the National Natural Science Foundation of China (81071996). 


\section{Disclosure}

The authors report no conflicts of interest in this work.

\section{References}

1. Man XB, Tang L, Zhang BH, et al. Upregulation of glypican-3 expression in hepatocellular carcinomas but downregulation in cholangiocarcinoma indicates its differential diagnosis value in primary liver cancers. Liver Int. 2005;25:962-966.

2. Lau WY, Lai EC. Hepatocellular carcinoma: current management and recent advances. Hepatobiliary Pancreat Dis Int. 2008; 237-257.

3. Reimer P, Weissleder R, Wittenberg J, Brady TJ. Receptor directed contrast agents for MR imaging: preclinical evaluation with affinity assays. Radiology. 1992;182:565-569.

4. Jia FG, Zhang XD, Xu YK, Meng Z. Synthesis of Gal-BSA-SPIO and magnetic resonance imaging of ASG receptors in rabbits bearing liver VX2 tumor and human liver. Nan Fang Yi Ke Da Xue Xue Bao. 2009;29:191-194. Chinese.

5. Lee CM, Jeong HJ, Kim EM, et al. Superparamagnetic iron oxide nanoparticles as a dual imaging probe for targeting hepatocytes in vivo. Magn Reson Med. 2009;62:1440-1446.

6. Huo T, Du X, Zhang S, Liu X, Li X. Gd-EDDA/HYNIC-RGD as an MR molecular probe imaging integrin $\alpha \mathrm{v} \beta 3$ receptor-expressed tumor-MR molecular imaging of angiogenesis. Eur J Radiol. 2010;73:420-427.

7. Wang XD, Wu GQ, Ju HS, et al. Preparation of MR molecular probe targeting integrin $\alpha v \beta 3$ receptor and its in vitro imaging. J Southeast Uni (Med Sci Edi). 2009;28:470-473.

8. Corbin IR, Li H, Chen J, et al. Low-density lipoprotein nanoparticles as magnetic resonance imaging contrast agents. Neoplasia. 2006;8:488-498.

9. Crich SG, Lanzardo S, Alberti D, et al. Magnetic resonance imaging detection of tumor cells by targeting low-density lipoprotein receptors with Gd-loaded low-density lipoprotein particles. Neoplasia. 2007;9:1046-1056.

10. Lauffer RB. Paramagnetic metal complexes as water proton relaxation agents for NMR imaging: theory and design. Chem Rev. 1987;87: 901-927.

11. Rosenthal SG, Willich HC, Ebert W, Conrad J. The demonstration of human tumors on nude mice using gadolinium-labeled monoclonal antibodies for magnetic resonance imaging. Invest Radiol. 1993;28: 789-793.

12. Renshaw PF, Owen CS, McLaughlin AC, Frey TG, Leigh LS Jr. Ferromagnetic contrast agents: a new approach. Magn Reson Med. 1986;3:217-225.

13. Srivastava S, Gopal Srivastava R. Biomarkers in cancer screening: a public health perspective. J Nutr. 2002;132:2471S-2475S

14. Collier J, Sherman M. Screening for hepatocellular carcinoma. Hepatology. 1998;27:273-278.

15. Nguyen MH, Garcia RT, Simpson PW, Wright TL, Keefe EB. Racial differences in effectiveness of alpha-fetoprotein for diagnosis of hepatocellular carcinoma in hepatitis $\mathrm{C}$ virus cirrhosis. Hepatology. 2002;36:410-417.

16. Soresi M, Magliarisi C, Campagna P, et al. Usefulness of alphafetoprotein in the diagnosis of hepatocellular carcinoma. Anticancer Res. 2003;23:1747-1753.

17. Saffroy R, Pham P, Reffas M, Takka M, Lemoine A, Debuire B. New perspectives and strategy research biomarkers for hepatocellular carcinoma. Clin Chem Lab Med. 2007;45:1169-1179.
18. Kandil D, Leiman G, Allegretta M, et al. Glypican-3 immunocytochemistry in liver fine-needle aspirates: a novel stain to assist in the differentiation of benign and malignant liver lesions. Cancer. 2007;111:316-322.

19. Ligato S, Mandich D, Cartun RW. Utility of glypican-3 in differentiating hepatocellular carcinoma from other primary and metastatic lesions in FNA of the liver: an immunocytochemical study. Mod Pathol. 2008;21:626-631.

20. Leuschner C, Kumar CS, Hansel W, Soboyejo, Zhou J, Hormes J. LHRHconjugated magnetic iron oxide nanoparticles for detection of breast cancer metastases. Breast Cancer Res Treat. 2006;99:163-176.

21. Hermanson GT. Polymeric microspheres and nanoparticles. In: Bioconjugate Techniques. 2nd ed. New York, NY: Academic Press; 2008.

22. Funovics MA, Kapeller B, Hoeller C, et al. MR imaging of the her2/ neu and 9.2.27 tumor antigens using immunospecific contrast agents. Magn Reson Imaging. 2004;22:843-850.

23. de Freitas ER, Soares PR, Santos R de P, et al. In vitro biological activities of anionic gamma- $\mathrm{Fe}_{2} \mathrm{O}_{3}$ nanoparticles on human melanoma cells. J Nanosci Nanotechnol. 2008;8:2385-2391.

24. Mahmoudi M, Simchi A, Milani AS, et al. Cell toxicity of superparamagnetic iron oxide nanoparticles. J Colloid Interface Sci. 2009;336:510-518.

25. Wu X, Tan Y, Mao H, Zhang M. Toxic effects of iron oxide nanoparticles on human umbilical vein endothelial cells. Int $J$ Nanomedicine. 2010;5:385-399.

26. Wilhelm C, Billotey C, Roger J, Pons JN, Bacri JC, Gazeau F. Intracellular uptake of anionic superparamagnetic nanoparticles as a function of their surface coating. Biomaterials. 2003;24:1001-1011.

27. MaYJ, Gu HC. Study on the endocytosis and the internalization mechanism of aminosaline-coated $\mathrm{Fe}_{3} \mathrm{O}_{4}$ nanoparticles in vitro. J Mater Sci Mater Med. 2007;18:2145-2149.

28. Billotey C, Wilhelm C, Devaud M, Bacri JC, Bittoun J, Gazeau F. Cell internalization of anionic maghemite nanoparticles: quantitative effect on magnetic resonance imaging. Magn Reson Med. 2003;49: 646-654.

29. Cedervall T, Lynch I, Lindman S, et al. Understanding the nanoparticle-protein corona using methods to quantify exchange rates and affinities of proteins for nanoparticles. Proc Natl Acad Sci U SA. 2007;104:2050-2055.

30. Mahmoudi M, Simchi A, Imani M, et al. A new approach for the in vitro identification of the cytotoxicity of superparamagnetic iron oxide nanoparticles. Colloids Surf B Interfaces. 2010;75:300-309.

31. Walczyk D, Bombelli FB, Monopoli MP, Lynch I, Dawson KA. What the cell "sees" in bionanoscience. J Am Chem Soc. 2010;132:5761-5768.

32. Tseng HH, Chang JG, Hwang YH, Yeh KT, Chen YL, Yu HS. Expression of hepcidin and other iron-regulatory genes in human hepatocellular carcinoma and its clinical implications. J Cancer Res Clin Oncol. 2009;135:1413-1420.

33. Dawson KA, Salvati A, Lynch I. Nanotoxicology: nanoparticles reconstruct lipids. Nat Nanotechnol. 2009;4:84-85.

34. Zhang Y, Kohler N, Zhang M. Surface modification of superparamagnetic magnetite nanoparticles and their intracellular uptake. Biomaterials. 2002;23:1553-1561.

35. Kircher MF, Mahmood U, King RS, Weissleder R, Josephson L. A multimodal nanoparticle for preoperative magnetic resonance imaging and intraoperative optical brain tumor delineation. Cancer Res. 2003;63:8122-8125. 


\section{Supplementary figures}

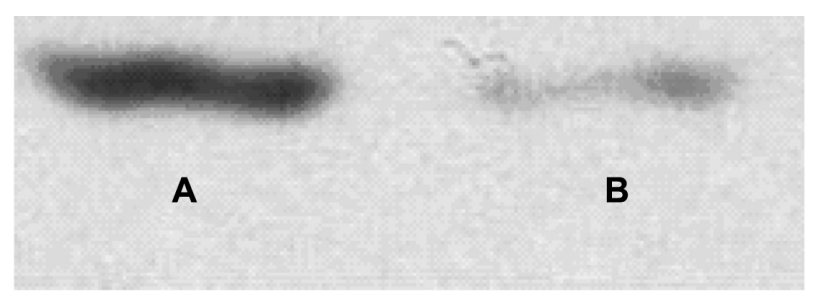

Figure SI Identification of GPC3 protein expression in HepG2 cell. (A) Purified GPC3 protein; (B) HepG2 cell.

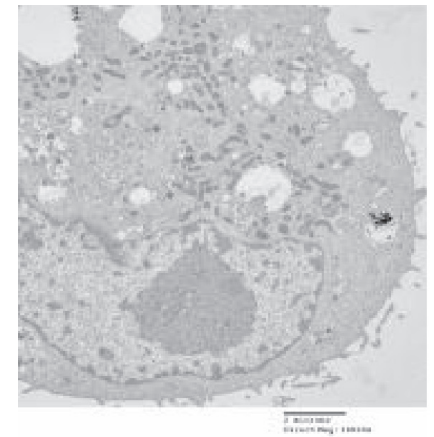

$62.5 \mu \mathrm{g} / \mathrm{mL}$ antiGPC3-USPIO

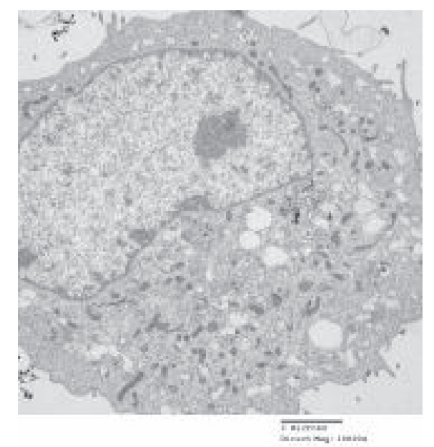

$62.5 \mu \mathrm{g} / \mathrm{mL}$ antiAFP-USPIO

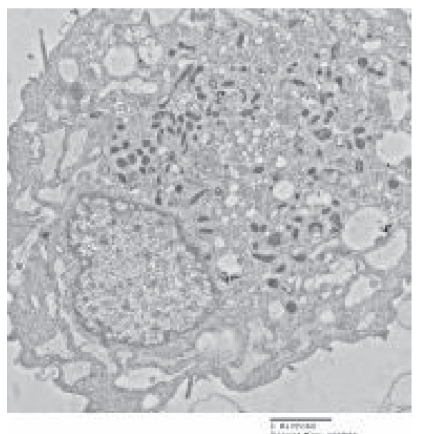

$62.5 \mu \mathrm{g} / \mathrm{mL}$ USPIO

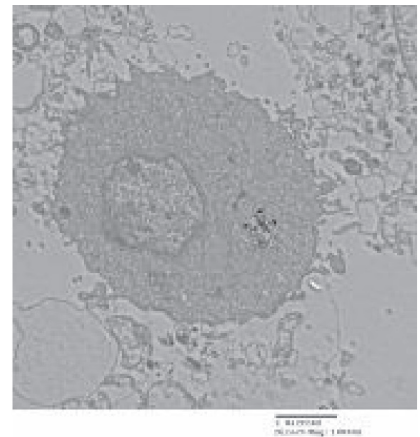

$250 \mu \mathrm{g} / \mathrm{mL}$ antiGPC3-USPIO

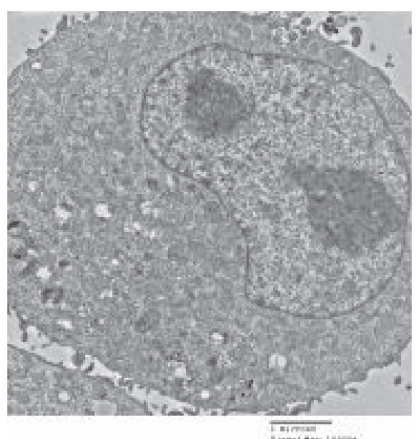

$250 \mu \mathrm{g} / \mathrm{mL}$ antiAFP-USPIO

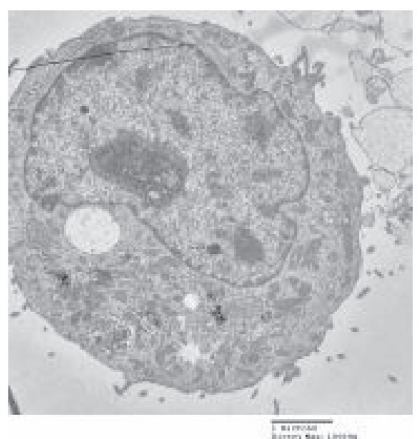

$250 \mu \mathrm{g} / \mathrm{mL}$ USPIO

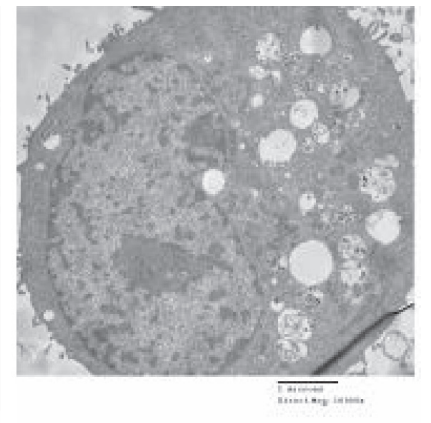

$750 \mu \mathrm{g} / \mathrm{mL}$ antiGPC3-USPIO

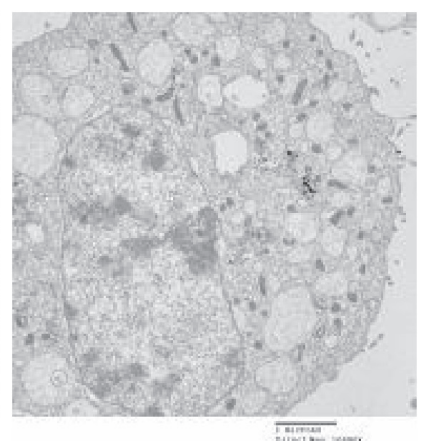

$750 \mu \mathrm{g} / \mathrm{mL}$ antiAFP-USPIO

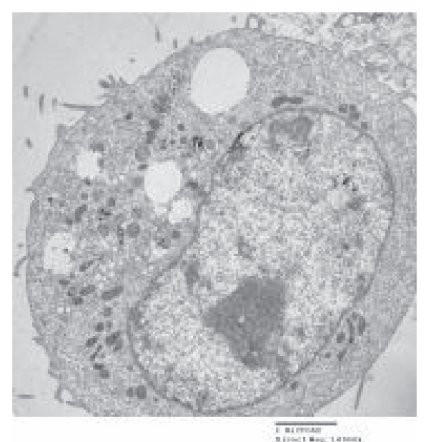

$750 \mu \mathrm{g} / \mathrm{mL}$ USPIO

Figure S2 Hitach 7600 TEM demonstrates construction of the SMMC-772I cells, incubated with $750 \mu \mathrm{g} / \mathrm{mL}, 250 \mu \mathrm{g} / \mathrm{mL}$, and $62.5 \mu \mathrm{g} / \mathrm{mL}$ iron content of antiGPC3-USPIO, antiAFP-USPIO and USPIO for $4 \mathrm{~h}$ at $37^{\circ} \mathrm{C}$ in $5 \% \mathrm{CO}_{2}$, with a magnification of 10,000 .

Note: The SMMC-772I cells took iron oxides increasingly in a concentration-dependent manner. 


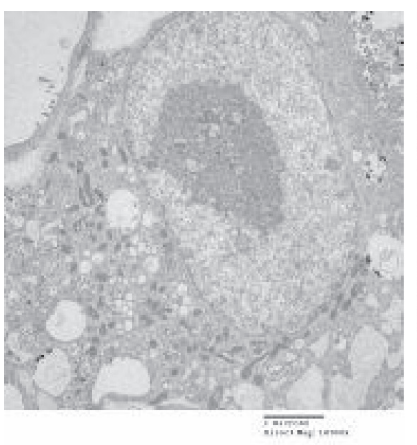

antiGPC3-USPIO $1 \mathrm{~h}$

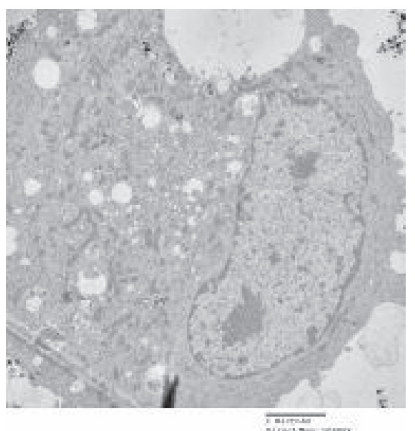

antiAFP-USPIO $1 \mathrm{~h}$

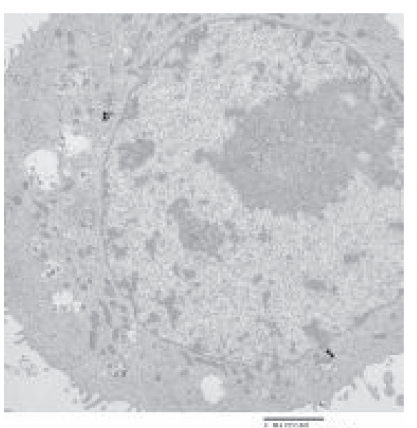

USPIO $1 \mathrm{~h}$

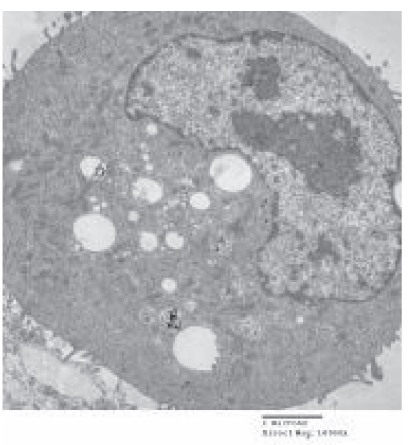

antiGPC3-USPIO $2 \mathrm{~h}$

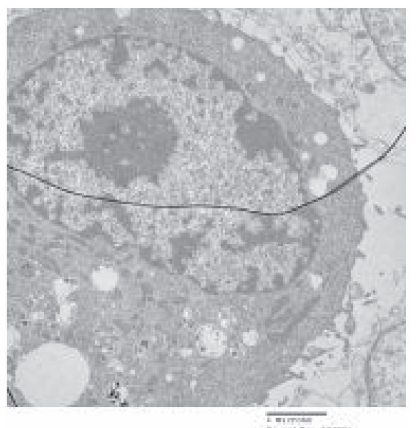

antiAFP-USPIO $2 \mathrm{~h}$

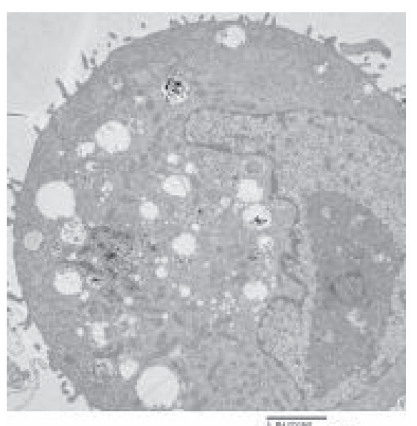

USPIO $2 \mathrm{~h}$

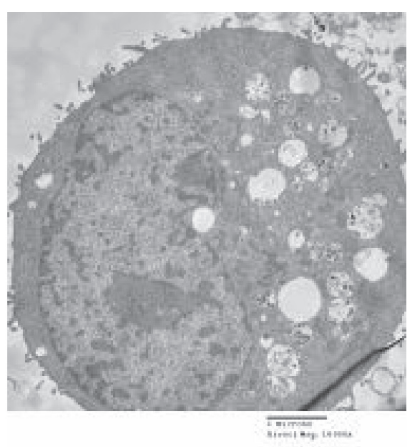

antiGPC3-USPIO $4 \mathrm{~h}$

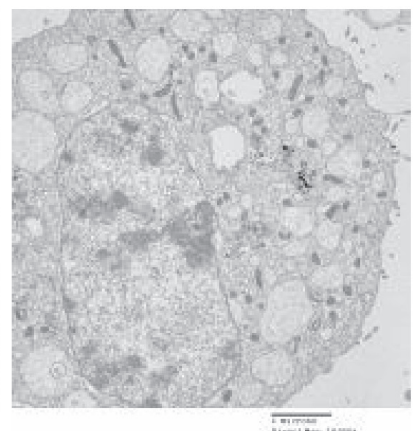

antiAFP-USPIO $4 \mathrm{~h}$

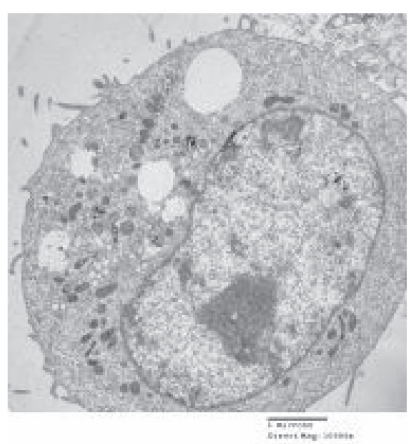

USPIO $4 \mathrm{~h}$

Figure S3 Hitach 7600 TEM demonstrates iron oxide incorporation by SMMC-772I cells incubated with $750 \mu \mathrm{g} / \mathrm{mL}$ iron content of antiGPC3-USPIO, antiAFP-USPIO and USPIO at $37^{\circ} \mathrm{C}$ in $5 \% \mathrm{CO}_{2}$, in time-dependent manner with a magnification of 10,000 .

Notes: The USPIO nanoparticles scattered around the SMMC-772I cell membrane and cytoplasma after I h incubation. For $2 \mathrm{~h}$ and $4 \mathrm{~h}$ incubation the amount of USPIO nanoparticles incorporated into intracellular increased and fused gradually, and became masses. 


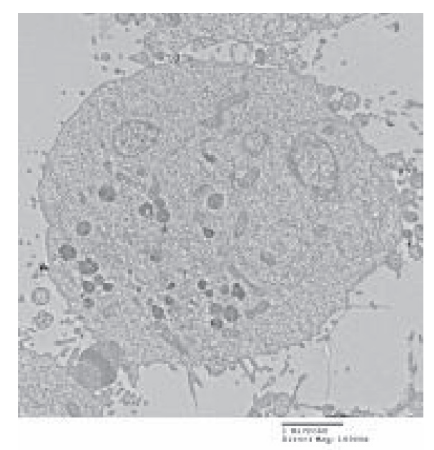

$62.5 \mu \mathrm{g} / \mathrm{mL}$ antiGPC3-USPIO

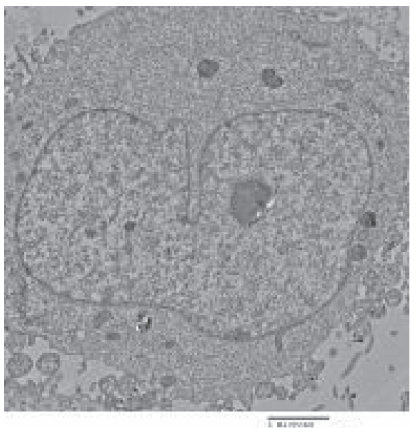

$62.5 \mu \mathrm{g} / \mathrm{mL}$ antiAFP-USPIO

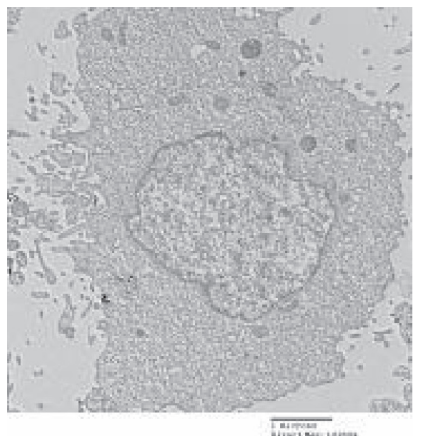

$62.5 \mu \mathrm{g} / \mathrm{mL}$ USPIO

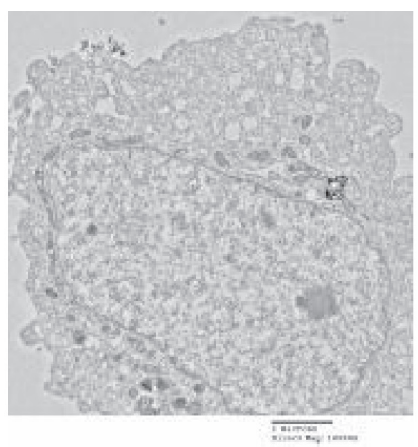

$250 \mu \mathrm{g} / \mathrm{mL}$ antiGPC3-USPIO

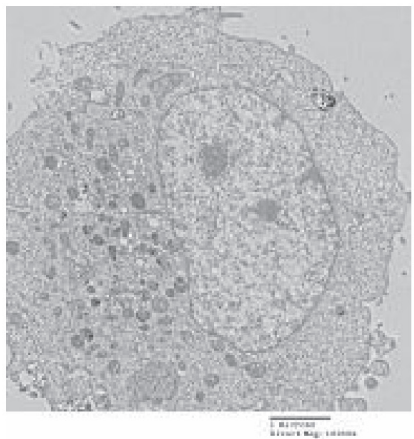

$250 \mu \mathrm{g} / \mathrm{mL}$ antiAFP-USPIO

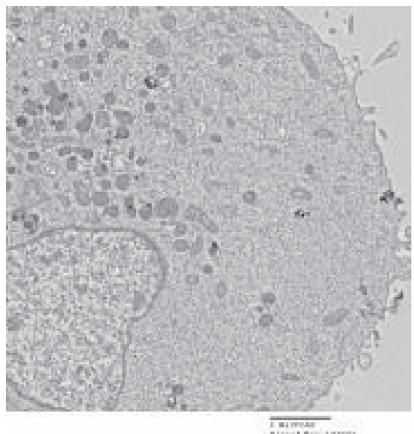

$250 \mu \mathrm{g} / \mathrm{mL}$ USPIO

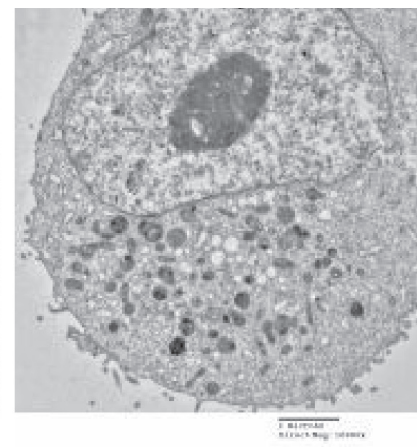

$750 \mu \mathrm{g} / \mathrm{mL}$ antiGPC3-USPIO

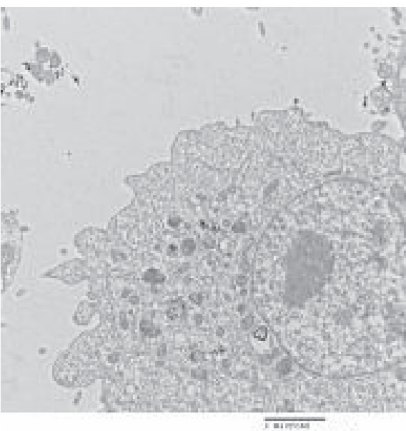

$750 \mu \mathrm{g} / \mathrm{mL}$ antiAFP-USPIO

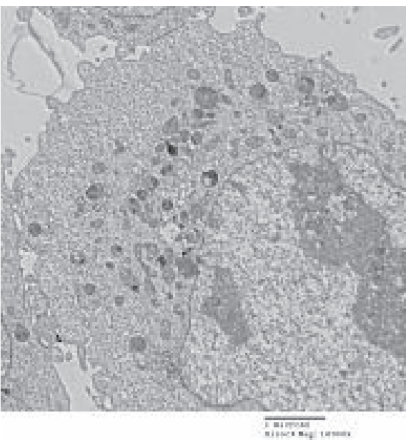

$750 \mu \mathrm{g} / \mathrm{mL}$ USPIO

Figure S4 Hitach 7600 TEM demonstrates construction of the Hela cells, incubated with $750 \mu \mathrm{g} / \mathrm{mL}, 250 \mu \mathrm{g} / \mathrm{mL}$, and $62.5 \mu \mathrm{g} / \mathrm{mL}$ iron content of antiGPC3-USPIO, antiAFPUSPIO, and USPIO for $4 \mathrm{~h}$ at $37^{\circ} \mathrm{C}$ in $5 \% \mathrm{CO}_{2}$, with a magnification of 10,000 .

Note: The Hela cells took iron oxides increasingly in a concentration-dependent manner. 


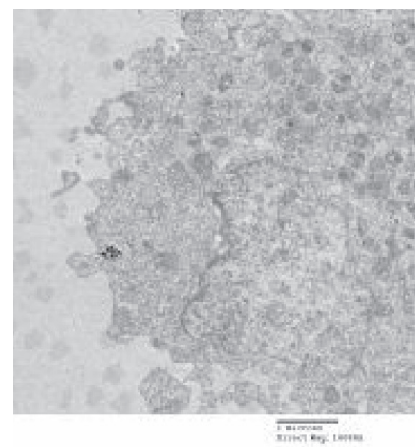

antiGPC3-USPIO $1 \mathrm{~h}$

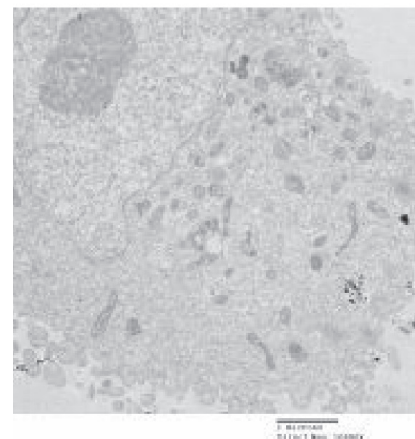

antiAFP-USPIO $1 \mathrm{~h}$

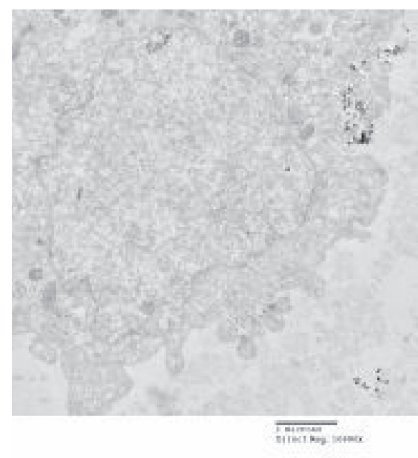

USPIO $1 \mathrm{~h}$

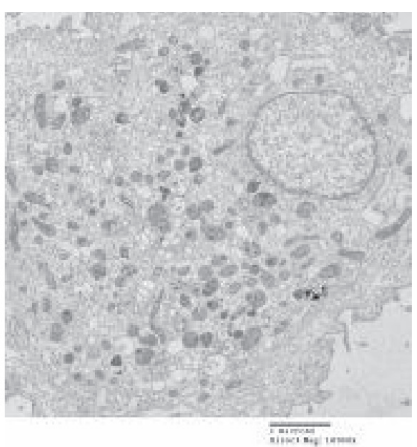

antiGPC3-USPIO $2 \mathrm{~h}$

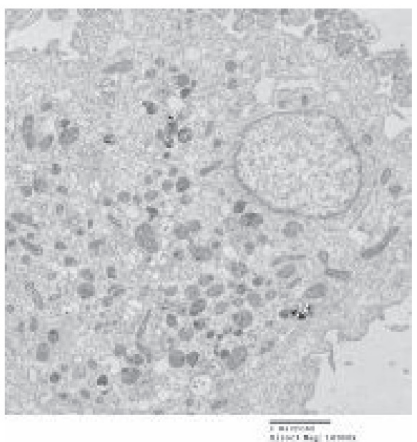

antiAFP-USPIO $2 \mathrm{~h}$

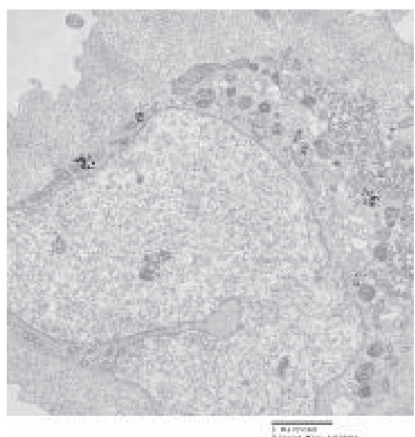

USPIO $2 \mathrm{~h}$

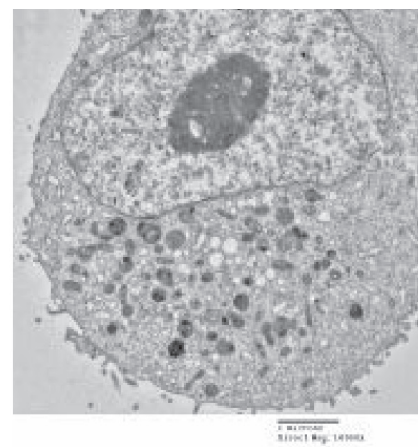

antiGPC3-USPIO $4 \mathrm{~h}$

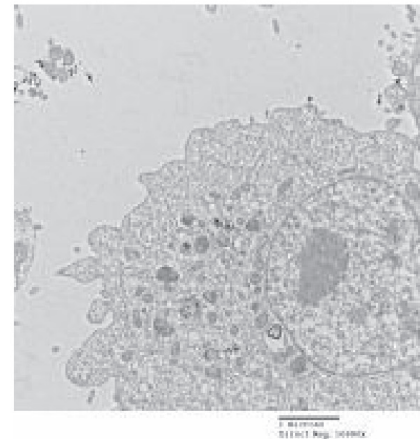

antiAFP-USPIO $4 \mathrm{~h}$

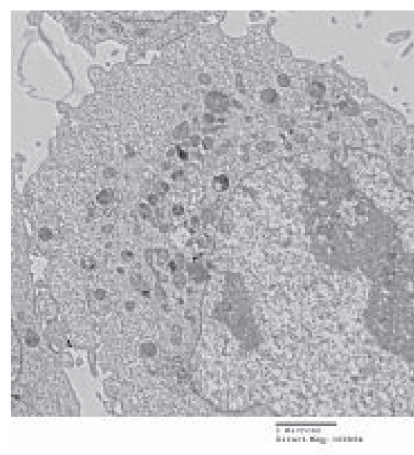

USPIO $4 \mathrm{~h}$

Figure S5 Hitach 7600 TEM demonstrates iron oxide incorporation by Hela cells incubated with $750 \mu \mathrm{g} / \mathrm{mL}$ iron content of antiGPC3-USPIO, antiAFP-USPIO, and USPIO at $37^{\circ} \mathrm{C}$ in $5 \% \mathrm{CO}_{2}$, in time-dependent manner with a magnification of 10,000 .

Notes: The USPIO nanoparticles scattered around the Hela cell membrane and cytoplasma after I $\mathrm{h}$ incubation. For $2 \mathrm{~h}$ and $4 \mathrm{~h}$ incubation the amount of USPIO nanoparticles incorporated into intracellular increased and fused gradually, and became masses. 
A

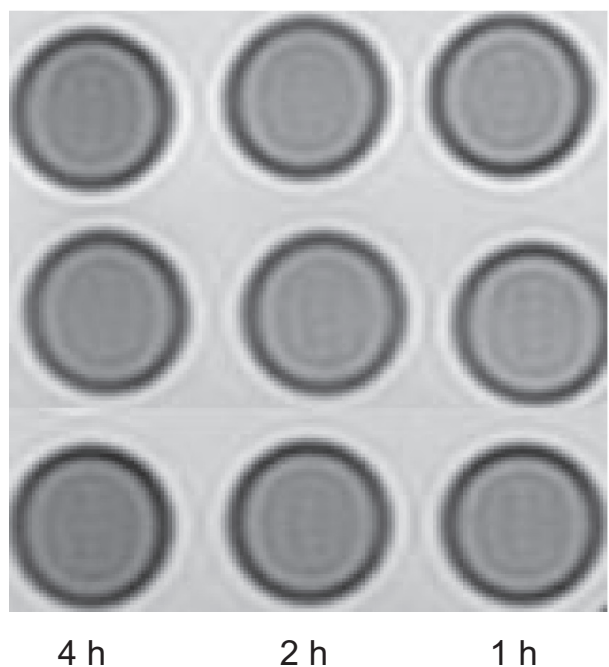

B

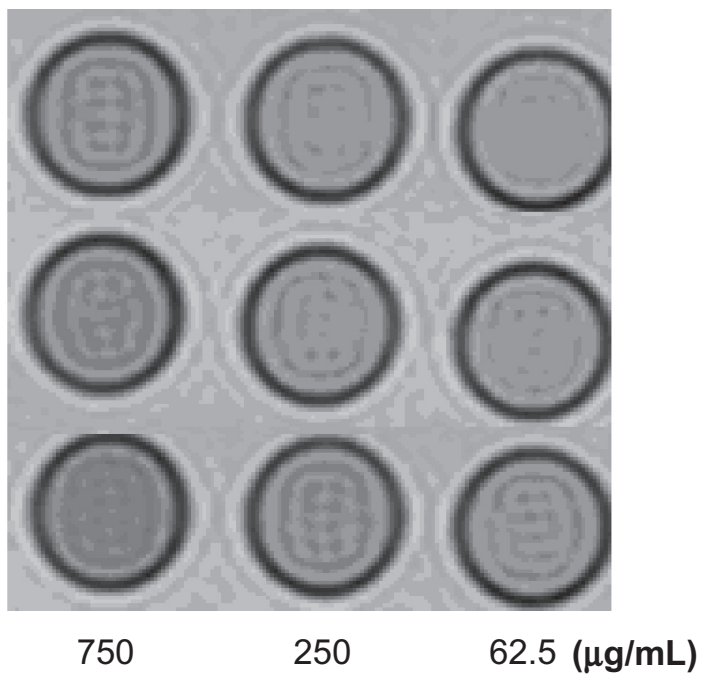

Figure S6 The T2W images (TR/TE $=2500 / 62.5 \mathrm{~ms}$, NEX 2.0, FOV $192 \times 160$, slice thickness $5 \mathrm{~mm}$ ) of tubes containing $3 \mathrm{~mL}$ solution of $2 \%$ agar mixed with $2.5 \times 10^{6} \mathrm{SMMC}$ $772 \mathrm{I}$ cells incubated with antiGPC3-USPIO, antiAFP-USPIO, and USPIO nanoparticles respectively. (A) the SMMC-772I cells incubated with iron content of $750 \mu g / \mathrm{mL}$ in antiGPC3-USPIO (top row), antiAFP-USPIO (middle row), and USPIO nanoparticles (below row) for $4 \mathrm{~h}, 2 \mathrm{~h}$, and I h at $37^{\circ} \mathrm{C}$ in $5 \%$ CO, (B) the SMMC-772I cells incubated with varied iron content (from left to right: $750 \mu \mathrm{g} / \mathrm{mL}, 250 \mu \mathrm{g} / \mathrm{mL}$, and $62.5 \mu \mathrm{g} / \mathrm{mL}$ ) of antiGPC3-USPIO (top row), antiAFP-USPIO (middle row), and USPIO nanoparticles (below row) for $4 \mathrm{~h}$ at $37^{\circ} \mathrm{C}$ in $5 \% \mathrm{CO}_{2}$.

A

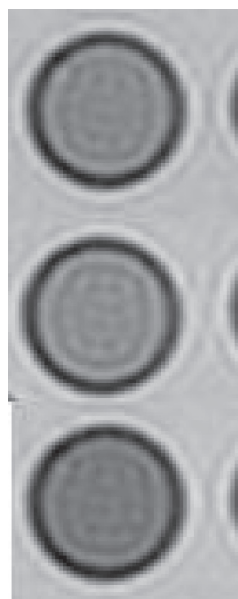

$4 \mathrm{~h}$

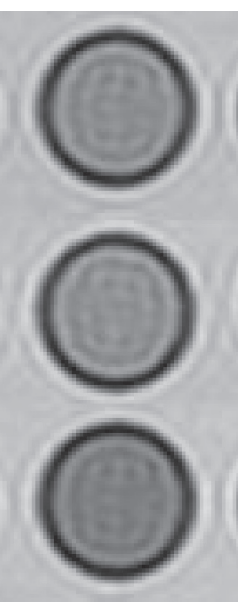

$2 \mathrm{~h}$

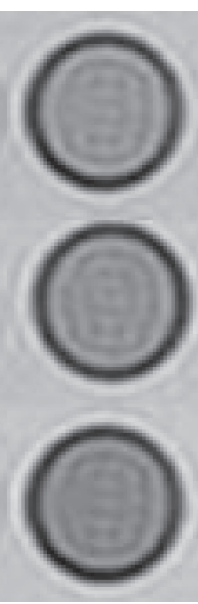

$1 \mathrm{~h}$
B

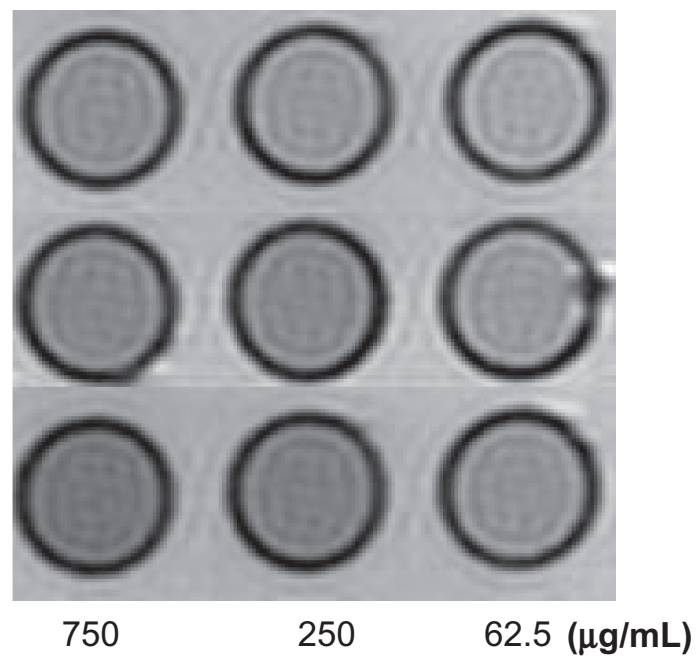

Figure S7 The T2W images (TR/TE $=2500 / 62.5 \mathrm{~ms}$, NEX 2.0, FOV $192 \times 160$, slice thickness $5 \mathrm{~mm}$ ) of tubes containing $3 \mathrm{~mL}$ solution of $2 \%$ agar mixed with $2.5 \times 10^{6}$ Hela cells incubated with antiGPC3-USPIO, antiAFP-USPIO, and USPIO nanoparticles respectively. (A) the Hela cells incubated with iron content of $750 \mu \mathrm{g} / \mathrm{mL}$ in antiGPC3USPIO (top row), antiAFP-USPIO (middle row), and USPIO nanoparticles (below row) for $4 \mathrm{~h}, 2 \mathrm{~h}$, and I h at $37^{\circ} \mathrm{C}$ in $5 \% \mathrm{CO}_{2}$; (B) the Hela cells incubated with varied iron content (from left to right: $750 \mu \mathrm{g} / \mathrm{mL}, 250 \mu \mathrm{g} / \mathrm{mL}$, and $62.5 \mu \mathrm{g} / \mathrm{mL}$ ) of antiGPC3-USPIO (top row), antiAFP-USPIO (middle row), and USPIO nanoparticles (bottom) for $4 \mathrm{~h}$ at $37^{\circ} \mathrm{C}$ in $5 \% \mathrm{CO}_{2}$. 

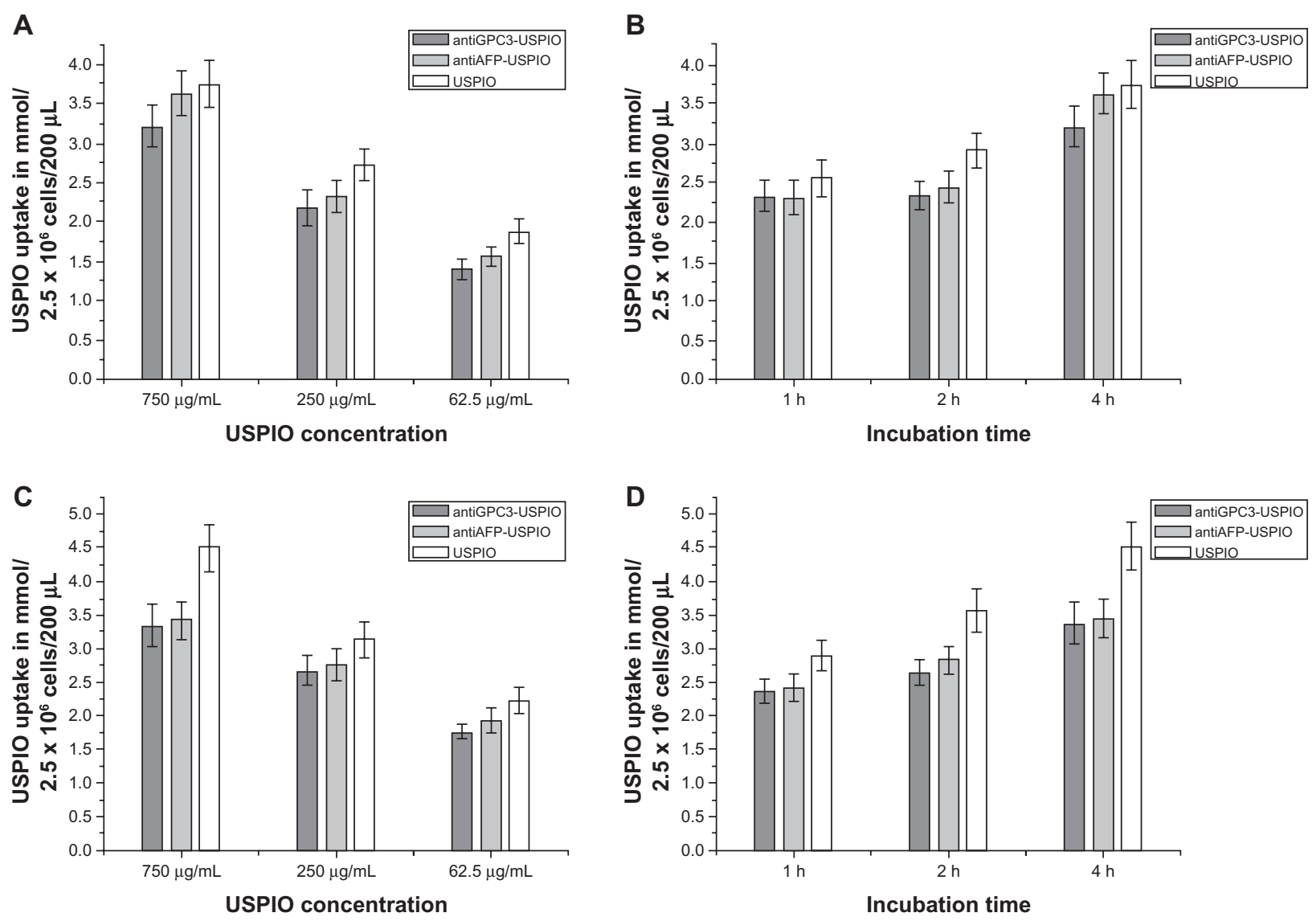

Figure S8 The iron uptakes by SMMC cells (A and B) or Hela cells (C and D) with a concentration-dependent manner, by which SMMC cells were incubated with antiGPC3-USPIO, antiAFP-USPIO, and USPIO nanoparticles at iron concentrations of $62.5 \mu \mathrm{g} / \mathrm{mL}, 250 \mu \mathrm{g} / \mathrm{mL}$, and $750 \mu \mathrm{g} / \mathrm{mL}$ for $4 \mathrm{~h}$ under equivalent incubation conditions, or in a time-dependent manner, by which SMMC cells were incubated with $750 \mu \mathrm{g} / \mathrm{mL}$ antiGPC3-USPIO, antiAFP-USPIO, and USPIO nanoparticles for I h, $2 \mathrm{~h}$, and $4 \mathrm{~h}$, respectively.

\section{Publish your work in this journal}

The International Journal of Nanomedicine is an international, peerreviewed journal focusing on the application of nanotechnology in diagnostics, therapeutics, and drug delivery systems throughout the biomedical field. This journal is indexed on PubMed Central, MedLine, CAS, SciSearch ${ }^{\circledR}$, Current Contents ${ }^{\circledR} /$ Clinical Medicine,
Journal Citation Reports/Science Edition, EMBase, Scopus and the Elsevier Bibliographic databases. The manuscript management system is completely online and includes a very quick and fair peer-review system, which is all easy to use. Visit http://www.dovepress.com/ testimonials.php to read real quotes from published authors. 